\title{
Public Policy and Financial Resource Mobilization for Wind Energy in Developing Countries: A Comparison of Approaches and Outcomes in China and India
}

Kavita Surana and Laura Diaz Anadon

Belfer Center for Science and International Affairs

Harvard Kennedy School, Harvard University

\begin{abstract}
We analyze and contrast how China and India mobilized financial resources to build domestic technological innovation systems in wind energy. To that end, we identify distinct stages of technology diffusion in the two countries in the period 1986-2012, and analyze the interplay between public policies and the development of the technological innovation system across the different stages. We show that the two countries' distinct development strategies for wind energy — China developed wind energy largely through its state-owned enterprises, while India opened up wind energy investment to the private sector in the early 1990sinfluenced system outcomes in terms of technology diffusion, domestic industry structure, competitiveness, and ownership. By unraveling the interplay between public policies, investment risks and returns, and actor characteristics, we explain the differences in system outcomes and identify important policy trade-offs between the two strategies. Our analysis provides novel insights about the process of financial resource mobilization in technological innovation systems, the dynamics of innovation-system growth, and the policy trade-offs that must be reconciled by countries that aim to promote the diffusion of a particular technology.
\end{abstract}




\section{Introduction}

Avoiding dangerous climate change will require a rapid up-scaling and redirection of energy infrastructure investments. Global investment in renewable energy has grown from $\$ 39.5 \mathrm{bn}$ to $\$ 214.4 \mathrm{bn}$ in the decade between 2004 and 2013 (Frankfurt School-UNEP Centre/BNEF, 2014), but will have to further increase to more than twice the current amount for the world to stay on track for mitigating dangerous climate change. Much of this investment will have to occur in developing countries, a term which we use as describing lowand middle-income countries (The World Bank, 2013). Their contribution will have to increase from roughly $40 \%$ in 2013 to almost $60 \%$ of the cumulative investments between 2015 and 2035 (IEA, 2014). This growth will have to occur in spite of the often underdeveloped financial markets and regulatory frameworks in the developing world, which make it difficult for investors to raise capital (Khanna and Palepu, 1997; Rodrik, 2009). How governments in developing countries can create conditions that stimulate the diffusion and market penetration of renewable energy technologies into their existing power systems is therefore keenly debated among academics, governments, and international organizations (Huenteler, 2014; Jakob et al., 2014; UNEP et al., 2008).

Two separate streams of literature are addressing the question of how governments in developing countries can enable the diffusion of renewable energy. On the one hand, a growing body of literature analyzes how public policies affect investors in clean energy in developing countries (Bhattacharyya, 2013; Friebe et al., 2014; Frisari and Stadelmann, 2015; Schmidt, 2014; Shrimali et al., 2013; Waissbein et al., 2013). These studies provide an analytical framework to analyze the influence of different policy instruments on the ability by investors to mobilize financial resources (Wüstenhagen and Menichetti, 2012). But they often pay relatively little attention to the enabling systemic conditions - e.g., local technology supply chains, actor networks, and informal institutions - that need to be in place for technologies to diffuse. On the other hand, a growing number of studies apply the technological innovation systems (TIS) concept to analyze how actors, networks, and institutions interact in the diffusion of technology in the context of developing countries (for a review, see (Blum et al., 2015). The TIS concept provides a powerful framework to analyze the systemic conditions that collectively enable technology diffusion (Bergek et al., 2008; Hekkert et al., 2007). But the TIS literature so far has developed only a rudimentary understanding of the detailed processes and determinants of financial resource mobilization in innovation systems and how they interact with other system functions and outcomes (Musiolik et al., 2012).

This paper integrates the two literature streams to study how public policies affect the diffusion of clean energy in developing countries. In particular, we study the policy strategies pursued by China and India to develop their wind energy sectors. The aim is to analyze the relationship between government policies and what we call 'system outcomes' of the diffusion of wind energy in the two countries. In particular, we analyze (i) the timing and rate of wind energy diffusion, (ii) the size and competitiveness of the wind turbine manufacturing industry, and (iii) the degree to which wind energy is integrated in the larger electricity system. We adopt a systemic perspective anchored in the TIS literature, and add to this a detailed model of financial resource mobilization anchored in the literature on renewable energy investment. Using the two cases, we analyze (i) the patterns of technology diffusion in the two countries; and (ii) how the process of financial 
resource mobilization and diffusion enabled by actors in the TIS was impacted by the interplay between public policies, actor characteristics, and investment determinants.

The remainder of the paper is structured as follows. Section 2 describes the theoretical perspective. Section 3 describes our case, data, and methods used. Section 4 presents an analysis of the stages and timescales of technology diffusion, and the interplay between public policies, actor characteristics, and investment determinants. Section 5 discusses the dynamics of system building and the processes for financial resource mobilization followed by the relevant public policy trade-offs. Section 6 concludes with a brief summary of our analysis.

\section{Theoretical Perspective}

\subsection{Resource Mobilization in Technological Innovation Systems}

This paper adopts a systemic perspective anchored in TIS literature. Technological innovation systems (TIS) are defined here as "socio-technical systems focused on the development, diffusion and use of a particular technology (in terms of knowledge, product or both)" (Bergek et al., 2008). The structural components of TIS are actors, networks of actors, institutions (or rules that govern interactions, such as public policies), and technology. The TIS approach, historically used to analyze the emergence of specific clean energy technologies in industrialized countries (Markard et al., 2012), is increasingly being used to understand the diffusion of renewable energy technologies in the context of developing countries (for a review, see (Blum et al., 2015). This increased coverage of developing countries has also led to a greater emphasis on the geographical dimensions of TIS, i.e., the national or regional context of technology diffusion in developing countries taking into account the global contexts of technology and development (e.g., Binz et al., 2014; Coenen et al., 2012).

The TIS literature has shown that analyses of system functions can usefully point policymakers toward specific strengths or weaknesses of the TIS that enhance or limit diffusion of a technology and that may benefit from policy intervention (Bergek et al., 2008; Hekkert et al., 2007). The functions of TIS are knowledge development and diffusion, entrepreneurial experimentation, influence on the direction of search, resource mobilization, market formation, legitimation, and development of positive externalities (Bergek et al., 2008; Hekkert et al., 2007).

The TIS function of resource mobilization describes the extent to which different actors are able to mobilize human and financial capital. Resource mobilization can be analyzed over time by evaluating the volume of domestic or foreign capital investment (Bergek et al., 2008; Gosens and Lu, 2013), or by interviewing involved actors (Hekkert et al., 2007). Despite its clear importance in the growth of an innovation system around a new technology, there has been little research on resource mobilization (Farla et al., 2012; Karltorp, 2014; Musiolik et al., 2012). In particular, the "underlying concepts did not receive much attention" (Musiolik et al., 2012). Especially in developing countries - where underdeveloped capital markets and regulatory frameworks often make it difficult to raise financial resources to start a new technology sector (Rodrik, 
2009) - better understanding the process of financial resource mobilization and the underlying concepts is important to inform policymakers.

The development and diffusion of a technology is often conceptualized as a multi-stage process in TIS with a formative phase and a growth phase (Jacobsson and Lauber, 2006). For the purposes of this paper, diffusion refers to the market penetration of a particular technology within a specific country where the formative stage encompasses pre-commercial and early-commercial deployment of the technology; the growth phase encompasses the commercialization period after the takeoff in which diffusion accelerates rapidly, followed by a last period of widespread diffusion (see Table 1). In our description of widespread diffusion, the market for the technology in that country may continue to grow (in absolute terms and also as a percentage of the total demand) and may experience another wave of rapid growth depending on domestic factors or external factors that reflect trends in the global industry. Indeed, the patterns, drivers, and stages of wind market penetration in specific countries must be understood in the wider context of the wind energy industry, which is evolving and maturing at a global level in terms of the emergence of a dominant design and interactions between manufacturers, for example.

\begin{tabular}{|c|c|c|c|c|}
\hline \multirow{2}{*}{$\begin{array}{l}\text { Stages of technology } \\
\text { diffusion }\end{array}$} & \multicolumn{2}{|c|}{ Formative stage } & \multicolumn{2}{|c|}{ Growth stage } \\
\hline & Pre-commercialization & Early commercialization & Commercialization & Widespread diffusion \\
\hline Description & $\begin{array}{l}\text { Scattered, non-commercial } \\
\text { deployment, often in the } \\
\text { form of highly subsidized } \\
\text { demonstration projects }\end{array}$ & $\begin{array}{l}\text { Limited deployment, first } \\
\text { commercially oriented } \\
\text { entrants, often attracted by } \\
\text { significant government } \\
\text { subsidies }\end{array}$ & $\begin{array}{l}\text { Period of strong growth in } \\
\text { market size, with rapidly } \\
\text { growing number of actors, } \\
\text { technology diffusion is } \\
\text { widespread }\end{array}$ & $\begin{array}{l}\text { Stable or gradually } \\
\text { growing market for } \\
\text { established technology } \\
\text { (rapid growth may still } \\
\text { occur due to global or } \\
\text { industry-external trends) }\end{array}$ \\
\hline Key resources & \multicolumn{2}{|c|}{$\begin{array}{l}\text { Relatively modest financing needs, mostly for } R \& D \text {, } \\
\text { demonstration and early deployment }\end{array}$} & \multicolumn{2}{|c|}{ Large-scale financing needs for widespread diffusion } \\
\hline
\end{tabular}

Table 1: Conceptualization of stages of technology diffusion for the purposes of this paper

The transition between stages of diffusion depends critically on the extent to which actors across the system are able to mobilize resources. In the case of renewable energy technologies in the power sector, these actors include (i) users of technology (project owners or project developers); (ii) technology suppliers (e.g., manufacturers and component suppliers); (iii) providers of finance and capital (e.g., banks); (iv) grid operators and other electric utilities (e.g., electric distribution companies); (v) the government and other public sector authorities (Geels, 2005). In the formative stage, early deployment in demonstration projects and $R \& D$ requires modest volumes of high-risk financing that may come from government funding, venture capital, corporate R\&D budgets, etc. (Wüstenhagen and Menichetti, 2012). In the growth stage, the widespread diffusion of technology requires high volume of low-risk financing, typically provided by banks (Wüstenhagen and Menichetti, 2012).

In the following, we draw on the literature on renewable energy investment to get insights on the determinants of investment that enable financial resource mobilization along the different stages of diffusion. 


\subsection{Determinants of Resource Mobilization}

Financial resource mobilization for renewable energy has been examined in detail in the investment-oriented literature. From this literature's perspective, investors aim to maximize the expected return on investment of a project while minimizing all associated risks and uncertainties (Wüstenhagen and Menichetti, 2012). In this context, public policies can be therefore analyzed and evaluated with regard to their influence on the perceived risk-return profile of different actors (e.g., (Bergek et al., 2013; Friebe et al., 2014; Spratt et al., 2014; Waissbein et al., 2013). Based on the literature that focuses on drivers of investment for actors (Batlle et al., 2012; Justice, 2009; Waissbein et al., 2013), we compile a list of the main risks and returns-or investment determinants — associated with renewable projects (Table 2).

The literature highlights that the impact of specific investment determinants on actual investment changes with the characteristics of actors, as different actors exhibit different profit expectations and risk tolerances (Bergek et al., 2013). Actors may be publicly or privately owned, be small or large firms, etc., and these characteristics can influence their ability to mobilize resources. For example, in contrast to private companies, publicly-owned companies may be willing to accept higher financial risks and lower returns; large companies usually have more slack resources and a higher credit rating, and may be able to deploy large amounts of capital more easily.

\begin{tabular}{|c|c|}
\hline $\begin{array}{l}\text { Determinants of resource } \\
\text { mobilization by different } \\
\text { actors }\end{array}$ & Description of the determinant and of possible risk mitigation actions \\
\hline $\begin{array}{l}\text { Resource \& technology } \\
\text { availability }\end{array}$ & $\begin{array}{l}\text { Risk and uncertainty about how much renewable energy resources are available at site and how much can be } \\
\text { extracted; can be reduced through improved resource assessment and improved technological capabilities of } \\
\text { developers and manufacturers }\end{array}$ \\
\hline Financing availability & $\begin{array}{l}\text { Risk and uncertainty about how much financing will be available at what cost; can be reduced through government } \\
\text { guarantees and technological learning }\end{array}$ \\
\hline Project implementation risk & $\begin{array}{l}\text { Risk and uncertainty about permits, planning, construction, O\&M; can be reduced through skilled staff, } \\
\text { infrastructure, regulatory streamlining, etc. }\end{array}$ \\
\hline Grid \& transmission risk & $\begin{array}{l}\text { Risk and uncertainty about grid integration and grid management; can be reduced through improved management } \\
\text { (e.g. forecasting and scheduling), quality of grid infrastructure, mandates for interconnection of new plants }\end{array}$ \\
\hline Counterparty risk & $\begin{array}{l}\text { Risk and uncertainty about ability and willingness of offtaker (e.g., electric utility) to make payments to investors; } \\
\text { depends on contract enforcement, credit rating, and overall ease of doing business }\end{array}$ \\
\hline Power market risk & $\begin{array}{l}\text { Risk and uncertainty related to overall market outlook; affected by liberalization policies, long-term energy policy } \\
\text { framework, and long-term targets }\end{array}$ \\
\hline $\begin{array}{l}\text { Type of policy-induced } \\
\text { returns }\end{array}$ & Description \\
\hline Fiscal-based returns & Increase return on investment through tax credits, rebates, tax exemption etc. \\
\hline Price-based returns & $\begin{array}{l}\text { Increase return on investment through price-based support, e.g., guarantee revenue stream for power generation } \\
\text { through feed-in tariffs }\end{array}$ \\
\hline Quantity-based returns & $\begin{array}{l}\text { Increase return on investment through volume / quota obligations, tradable renewable energy certificates, } \\
\text { competitive auctions that increase demand for renewable power }\end{array}$ \\
\hline
\end{tabular}

Table 2: Most influential investment determinants and possible mitigating actions that drive renewable energy investments, adapted from (Batlle et al., 2012; Justice, 2009; Waissbein et al., 2013). 


\subsection{Framework to Analyze Resource Mobilization across Different Stages}

The insights from the energy-investment literature discussed above provide a conceptual basis to model the resource mobilization process in a technological innovation system and to guide and structure our empirical analysis. We conceptualize the process of resource mobilization and the relationship between public policy and system outcomes as depicted in Figure 1.

We model the influence of public policy on system outcomes as mediated by investment determinants, actor characteristics, and financial resource mobilization. Public policies directly affect investment determinants - i.e., technology- and time-specific risk and return factors that collectively constitute the riskreturn profile of investment decisions - for example by creating financial subsidies for investment, providing tax breaks, or by altering permitting processes (arrow a). Public policies also directly affect the types of eligible investors, e.g., through electricity-sector liberalization, privatization, and deregulation (b). The riskreturn profile of the technology determines the ability of actors to mobilize financial resources (c). But this relationship between investment determinants and financial resource mobilization is moderated, as discussed in Section 2.2, by relevant characteristics of the different types of actors (d), including firm size (large or small) and firm ownership (public or private). Finally, the mobilized financial resources affect, together with other systemic conditions that are not the focus of this framework, the system outcomes (e).

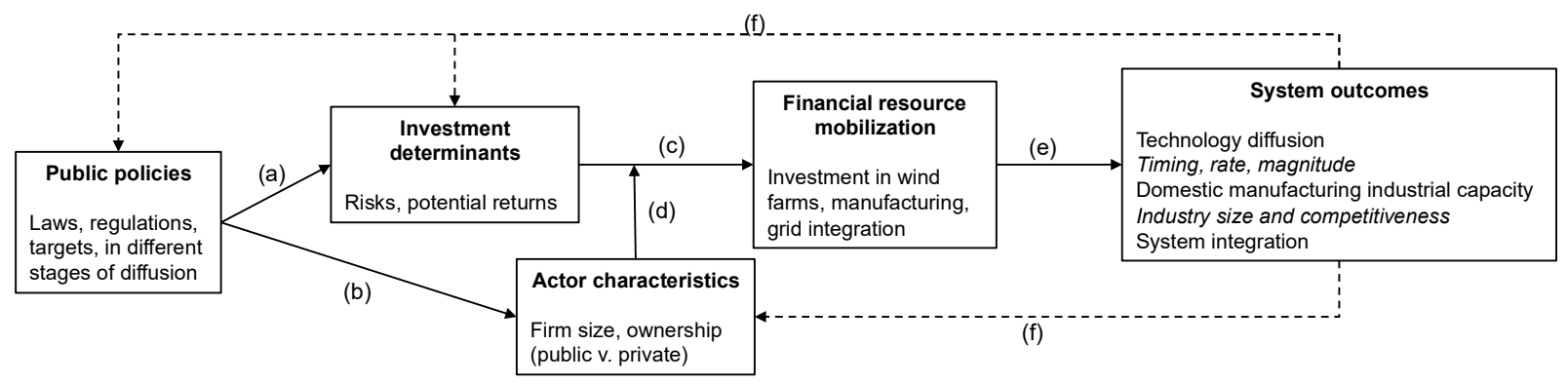

Figure 1: Framework for resource mobilization

In the medium- to long-term, the system outcomes can feed back into the policymaking process, the investment determinants, and actor characteristics (f). For example, governments may respond to slowerthan-expected diffusion by increasing subsidies; increased diffusion of a specific technology may reduce risk perception by investors; and over time market growth can allow firms to build up larger balance sheets that make large capital investments easier to finance, or can attract new investors.

\section{Data and Methodology}

In this section, we describe our research cases (3.1); lay out our approach for analyzing resource mobilization processes across different technology diffusion stages (3.2); and introduce our data sources (3.3). 


\subsection{Empirical Cases}

\subsubsection{Case Selection}

We chose the cases of China and India for our study of resource mobilization processes for three main reasons.

First, the two countries pursued very different strategies to mobilize resources for the diffusion of wind energy. The primary differences lie in the role of state-owned companies and the extent to which the state organizes and manages the mobilization of resources rather than the private sector, as described in more detail in Section 4. This is a choice many developing countries face when developing new sectors. China chose to develop wind energy largely under direct government control, within the existing set of large stateowned electric utilities, and encouraged a number of state-owned companies to engage in wind turbine manufacturing. Private capital only played a major role in the form of foreign minority investment in joint ventures for wind turbine manufacturing. India, in contrast, chose to develop wind energy largely outside of the existing partially state-owned electric utility sector, by opening up wind energy development and wind turbine manufacturing to private capital from the onset. (These differences are in part result of the broader development strategies of the two countries and conditioned by political-economy factors, which we summarize in Section 3.1.2). The differences in the policy strategies and actor characteristics between the two cases allow us to identify the interplay between public policies, resource mobilization processes, and system outcomes in detail.

Second, the two countries are the largest investors in wind energy outside the developed world and have ambitious plans to make wind energy a central part of their future energy systems. The developments in these two cases will therefore be important for understanding the future of wind energy globally. At the time of the first demonstration projects in China and India in the mid-1980s, the global wind industry was still at a relatively early stage of development with turbine technologies that had emerged from R\&D in industrialized countries such as Denmark, Germany, and USA (Lewis and Wiser, 2007). Both China and India can be considered part of a second wave of global wind industry growth. Between 1985 and 2013, both countries attracted sizeable investments in the wind energy sector - in 2013, China led annual global wind energy investments with \$28bn, and India was fifth with \$3.3bn (Frankfurt School-UNEP Centre/BNEF, 2014). Investment is likely to continue to grow-India's government is considering a goal of $100 \mathrm{GW}$ by 2022 (MNRE, 2015), up from over $18 \mathrm{GW}$ in 2012, while China is targeting $200 \mathrm{GW}$ by 2020 (NDRC, 2015), up from over $75 \mathrm{GW}$ in 2012. Both countries are also home to globally recognized wind turbine manufacturers. In 2012, top five Chinese manufacturers had a combined global market share of $17 \%$, while the one major Indian company had a global market share of 7\% (BTM Consult, 2013). Furthermore, between them, China and India emitted over 30\% of global carbon dioxide emissions in 2012 (Boden et al., 2013). Better understanding of the timing and trajectories of clean energy investment in the two countries is therefore crucial to inform global climate mitigation scenarios.

Third, the relative size of wind energy in the two countries is comparable, making them suitable for a comparative case study. While capacity investments in China are higher by nearly an order of magnitude, the current status of installed wind capacity in the two countries is comparable considering the relative size of the market - in 2011, wind energy comprised between $6 \%$ and $7 \%$ of the electricity capacity mix in both 
nations (Appendix A); generated wind electricity was $2 \%$ of total generation in China (for $6 \%$ share of installed capacity), and 3\% of total generation in India (for 7\% installed capacity) (EIA, 2014). This points toward a similar overall significance of wind power in the context of the two countries' electricity sectors.

\subsubsection{Case Context}

The development of the wind energy sectors in China and India has to be investigated in the context of the countries' broader economic development and political economy.

China's industrial development policy is often characterized as centralized and gradualist, with a prominent role for the government in the economy (Bardhan, 2010; Li et al., 2008). According to (Bardhan, 2010), highly centralized political power and a relatively homogenous society facilitate long-term planning. Longterm planning translates into incentives and guidelines for the domestic industry in three main ways. First, the state directly controls many large state-owned enterprises (SOEs), whose management is incentivized to execute government objectives. Second, the central government and local government holds stakes in many semi-private businesses. And third, the government provides a large number of specific targets to local governments and industries through five-year plans and industry-specific development plans, and thus sets guideposts that must be reached for the development of industries as a whole. The role of SOEs has hardly declined in many sectors despite a history of economic reforms since the early 1980s, including a series of reforms in the run-up to China's accession to the WTO in 2001 (Bardhan, 2010). SOEs are often relatively homogenous within sectors, not always profit-driven, and often quickly and aggressively enter new sectors in response to government directives (Ohara et al., 2011), with wind power being one of the many sectors of focus.

India's approach to industrial policy can be characterized as decentralized and volatile, with a focus on entrepreneurship and competition. India's contested democratic politics and heterogeneous society make execution of long-term targets conflict-ridden for the government, but ideas that do get implemented are often more legitimized (Bardhan, 2010). The government plays a much less prominent role in the economy than in China (even though India also has five-year plans). The first signs of economic reform came in the 1980s through the changing 'pro-business' political alignments of the ruling party that began to support the incumbent private sector rather than over-regulate it, followed by opening up of the economy in the 1990s through 'pro-market' reforms (Rodrik and Subramanian, 2004). The reforms in the early 1990s culminated in India's accession to the WTO in 1995, which pushed economic policy further towards liberalization, decentralization, and privatization (Dahlman, 2007). Today, the competitive environment can be described as profit-oriented, with large heterogeneity between firms (Ohara et al., 2011). However, India's economic growth is often hampered by relatively weak infrastructure, long bureaucratic delays, and a culture of corruption (Khanna et al., 2005).

\subsection{Empirical Strategy}

We analyze the interplay between public policies and investment determinants across different diffusion stages in the two countries in four main steps. First, grounded in the empirical dataset, and consistent with 
existing studies on technology diffusion, we use patterns in the annual incremental capacity additions to distinguish between the different stages of technology diffusion of wind turbines (Table 3). We also define and descriptively characterize different stages of technology diffusion, including timing, length, and growthrate of each stage. The division of technology diffusion into stages allows us to compare and contrast between the two countries the dynamic shifts in the process of financial resource mobilization over time. The percentage of new incremental diffusions is useful for normalizing over the absolute size of electricity demand and overall capacity expansion in both countries. Second, we created a timeline of major policies affecting wind investment decisions in India and China from 1986 through 2012 (Dai and Xue, 2014; Ganesan et al., 2014; Gosens and Lu, 2013; IRENA and GWEC, 2012; Jolly and Raven, 2013; Lewis, 2012; Mizuno, 2007). Third, we categorized each policy according to the affected investment determinants (see Appendix B and Appendix C for detailed policy tables) in order to identify patterns in the focus of policy support over time. Fourth, we characterized the actors involved in each diffusion stage and identified their role in the mobilization of resources for the diffusion of wind energy in the two countries.

\begin{tabular}{|c|c|c|c|c|}
\hline \multirow{2}{*}{$\begin{array}{l}\text { Operationalization of } \\
\text { stages of technology } \\
\text { diffusion }\end{array}$} & \multicolumn{2}{|c|}{ Formative stage } & \multicolumn{2}{|c|}{ Growth stage } \\
\hline & Pre-commercialization & Early commercialization & Commercialization & Widespread diffusion \\
\hline Start of stage & $\begin{array}{l}\text { First successful grid- } \\
\text { connected demonstration } \\
\text { project }\end{array}$ & $\begin{array}{l}\text { Increase in annual capacity } \\
\text { is more than } 50 \mathrm{MW} \text { for } \\
\text { three consecutive years, } \\
\text { which corresponds to } \\
\text { roughly } \$ 100 \text { million per } \\
\text { year of new capital } \\
\text { investment }\end{array}$ & $\begin{array}{l}\text { Increase in annual capacity } \\
\text { additions is greater than or } \\
\text { equal to } 10 \% \text { for three } \\
\text { consecutive years, } \\
\text { indicating strong growth }\end{array}$ & $\begin{array}{l}\text { Increase in annual capacity } \\
\text { additions is less than } 10 \% \\
\text { for three consecutive years, } \\
\text { indicating slowdown in } \\
\text { absolute capacity additions } \\
\text { with significant limits to } \\
\text { diffusion }\end{array}$ \\
\hline
\end{tabular}

Table 3: Operationalization of stages of technology diffusion

\subsection{Data}

Our analysis is structured as a comparative case study. The analysis of the investment patterns relies on a project-level wind farm database covering the period 1986 through 2012 for China and India. These proprietary datasets present investor-level information on a total of over 57,000 turbines for 149 owners for China, and over 23,000 turbines for 4,428 owners in India (CECL, 2013; Huaxia Wind, 2013). The datasets, in combination with other reports on wind energy deployment, were used to identify different stages of diffusion (4.1) and the relevant actors involved in the resource mobilization process over time (4.3). In order to assess the resource mobilization process in further detail, we complemented the analysis of patterns in actor characteristics with analysis of the evolution of national-level public policies, investment determinants, and resource mobilization processes in the wind farm development and wind turbine manufacturing industries in India and China (4.2; see also Appendix B and Appendix C). The qualitative analysis was based on archival data, including documents authored by government and regulatory bodies, annual reports by wind turbine manufacturers, reports by renewable and wind energy associations, academic literature, and news articles.

\section{Results}


This section presents our findings for how financial resource mobilization processes contributed to the different system outcomes. We first show the stages of technology diffusion and indicate patterns in the process of resource mobilization over time (4.1). Next, we present results of the analysis of the influence of public policies on investment determinants (4.2). Finally, we present the characteristics and evolution of the major actors involved in the wind energy sectors in the different stages of diffusion (4.3).

\subsection{Mobilized Resources and Patterns of Technology Diffusion}

By the end of 2012, China had installed over $75 \mathrm{GW}$ of wind capacity, in comparison to over $18 \mathrm{GW}$ installed in India, with annual growth rates of 15-20 GW per year in China and 1-3 GW per year in India. Given that wind energy projects in the developing world average \$1-\$2 per Watt (IRENA, 2012), this means that China and India were able to attract in the order of $\$ 100 \mathrm{bn}$ and $\$ 25 \mathrm{bn}$ in capital investment in wind farms, respectively, plus investment in wind turbine manufacturing plants, and are each attracting capital at the rate of several of billions of dollars per year in the wind sector.

However, despite the differences in absolute size, our analysis suggests that both India and China are now in the 'widespread diffusion' stage, having gone through all four stages of technology diffusion, starting with pre- and early commercialization (i.e., the formative period), followed by the stages of commercialization and widespread diffusion (i.e., the growth period). The different stages are shown together with the trends in annual capacity additions in the two countries (Figure 2, left axis) and summarized in Table 4. 

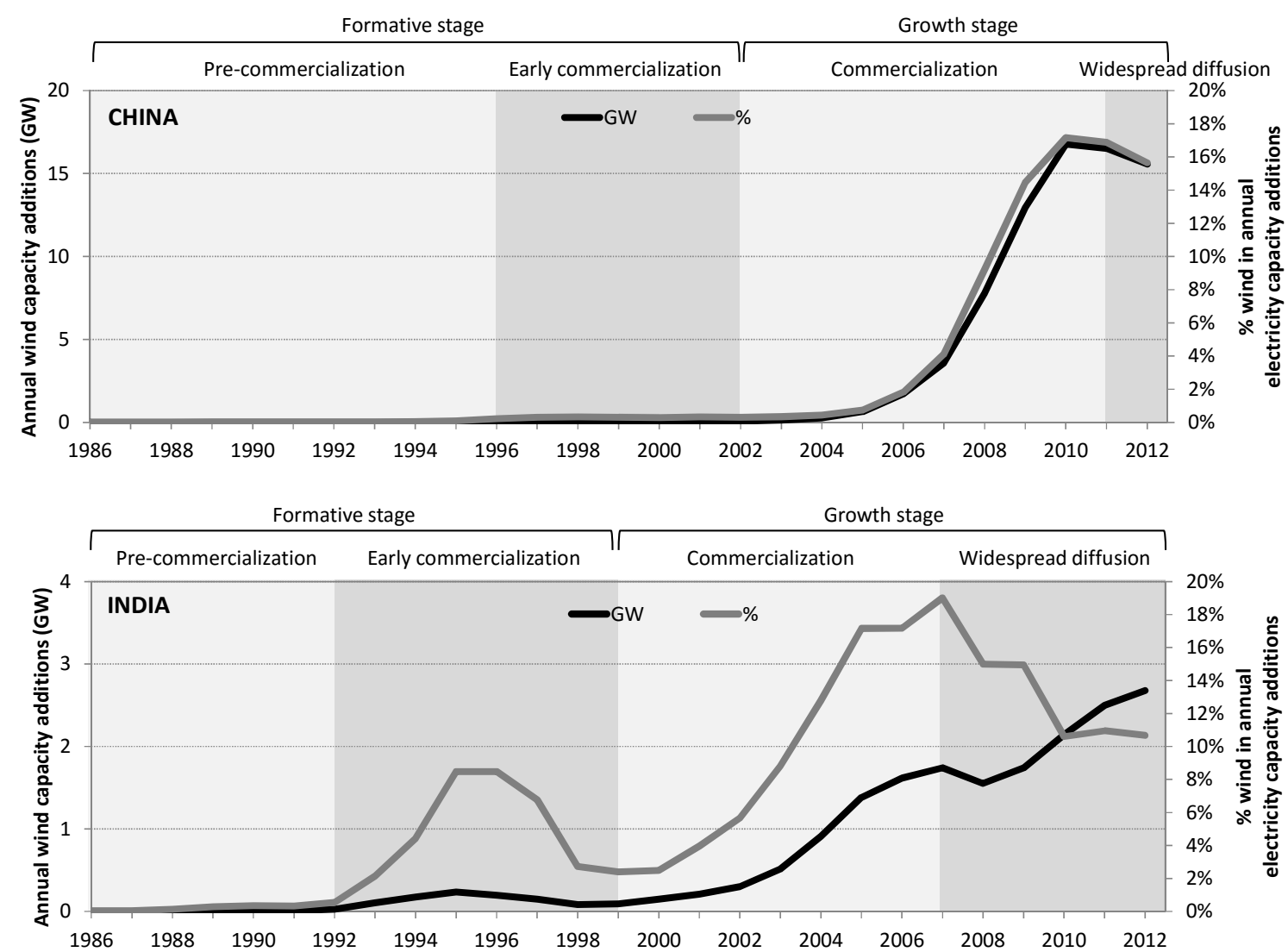

Figure 2: Different stages of wind energy diffusion in China and India. The black line (left axis) shows annual capacity additions. The grey line (right axis) indicates the percentage of wind power in total annual powersector capacity additions. We used three-year rolling averages for all variables to remove fluctuations in annual data.

In China, diffusion exhibited a relatively long formative period (1986-2002), followed by rapid and intense expansion in the late growth period (since 2002), which leveled off around 2010. China took 9 years to reach early commercialization, and a total of 16 years from the first installed turbine until commercialization fully took off. Once commercialization was reached, however, annual capacity additions quickly jumped by two orders of magnitude, from several hundreds of MW until 2005 to tens of GW from 2009. The growth rates of around 15-20 GW per year, in place since 2009, correspond to tens of billions of USD per year in capital investment. 


\begin{tabular}{|c|c|c|c|c|}
\hline \multirow{2}{*}{$\begin{array}{l}\text { Features of stages of } \\
\text { technology diffusion }\end{array}$} & \multicolumn{2}{|c|}{ Formative stage } & \multicolumn{2}{|c|}{ Growth stage } \\
\hline & Pre-commercialization & Early commercialization & Commercialization & Widespread diffusion \\
\hline \multicolumn{5}{|l|}{ China } \\
\hline Starting year & 1986 & 1996 & 2002 & 2011 \\
\hline Number of years in stage & 10 years & 6 years & 9 years & $3+$ years \\
\hline $\begin{array}{l}\text { Total capacity installed during } \\
\text { stage }\end{array}$ & $0.04 \mathrm{GW}$ & $0.37 \mathrm{GW}$ & $44.33 \mathrm{GW}$ & $30.59+\mathrm{GW}^{*}$ \\
\hline \multicolumn{5}{|l|}{ India } \\
\hline Starting year & 1986 & 1992 & 1999 & 2007 \\
\hline Number of years in stage & 6 years & 7 years & 8 years & $7+$ years \\
\hline $\begin{array}{l}\text { Total capacity installed during } \\
\text { stage }\end{array}$ & $0.04 \mathrm{GW}$ & $0.97 \mathrm{GW}$ & $5.23 \mathrm{GW}$ & $12.15+\mathrm{GW}^{*}$ \\
\hline
\end{tabular}

Table 4: Patterns of diffusion for wind energy technology in China and India. *This number represents the capacity installed in the widespread diffusion stage by the end of 2012.

In India, in contrast, wind energy diffusion was somewhat more erratic. India was a very early entrant into the commercialization of wind energy by global standards, installing more than $50 \mathrm{MW}$ per year already in 1992 , corresponding to roughly $\$ 100 \mathrm{mn}$ per year in capital investment, and more than $100 \mathrm{MW}$ per year in 1994. That means India took around 6 years to reach the early commercialization stage. However, the early momentum did not result in a stable market; installations fell below 100 MW per year again in 1997 and only took off really in 1999. Since then India has become a relatively large market for wind energy, but installations have experienced more volatility in comparison to China.

The diffusion patterns in the two countries suggest that the individual diffusion stages showed similar lengths in the two countries, but China entered each stage later than India - i.e., India had a head start in attracting significant amounts of capital to the wind energy sector. Once China entered commercialization, however, financial resources were mobilized much more rapidly and at a much larger scale in China. The most striking difference in growth between the two countries was during the commercialization stage. In India over $5 \mathrm{GW}$ were installed during commercialization over a period of 8 years while in China over $44 \mathrm{GW}$ were installed over a period of 9 years. We calculated that for cumulative installed capacity to grow from $10 \%$ to $90 \%$ of the 2012 values, China took 4 years as compared to 10 years in India, further stressing on the rate of growth during the commercialization stage in China. How was China able to attract so much investment so fast?

In terms of the relative share of wind capacity in total power sector capacity additions (shown in Figure 2, right axis), wind power in both countries peaks at a similar level, but the two countries reached that peak in different stages of diffusion. In China, the timing of the widespread diffusion stage coincides with the peak in the share of wind in new electricity capacity additions, at around 16\% in 2012. In India, we observe erratic trends in the share of wind in new electricity capacity additions, with a first peak during earlycommercialization (8\%), and a second during commercialization (19\%); the share declined around 2008 and remained flat around $10 \%$ after that. 
Despite the relatively large share of wind capacity additions in the electricity sector, both countries face problems. In China, grid and transmission issues underlie concerns over curtailment, idle turbines, and large distances between demand centers and wind farms. The variety of issues present in India range from unclear guidelines for land acquisition and general procedural delays, to distribution companies (discoms) that generally face considerable financial burdens (CECL, 2011; GWEC, 2012; IRENA and GWEC, 2012).

\subsection{Public Policies and Investment Characteristics}

Both countries implemented a number of policy instruments to stimulate diffusion and attract financial resources to the wind power sector. These policies affected the risk-return profile of wind investments, which enabled and incentivized different actors to invest and raise capital.

Our analysis of the focus of national-level wind policies implemented in China and India, shown in Figure 3 and Figure 4 respectively below, suggests that periods of rapid growth in both countries - in China in the commercialization stage and in India in the early-commercialization stage-were preceded by policies that addressed a particularly comprehensive spectrum of investment determinants simultaneously. Taken together, the policy instruments used by the each of the two governments over the last 30 years to stimulate wind energy diffusion addressed the entire spectrum of investment determinants.

\subsubsection{China}

We find that China implemented at least 37 major national-level policies and plans to stimulate wind power since 1986 (listed in detail in Appendix B). The focus of these instruments in terms of investment determinants is shown in Figure 3. The patterns revealed from this perspective suggest that the Chinese government (i) gradually expanded its policy-making focus in the wind sector, starting from technology and resource availability and increasingly taking into account other investment determinants; (ii) iteratively continued to revisit and revise the regulatory framework even after specific investment determinants were addressed; and (iii) ultimately addressed the entire spectrum of investment determinants.

Policy activity increased over time in line with cumulative installations, with most activity occurring in the early commercialization and commercialization stages. The first noteworthy policy to promote large-scale wind resource mobilization was the Concession Program of 2003 - project investors (owners and developers of wind farms) were selected for each site through a competitive bidding process. They built wind farms under certain requirements (such as the localization rate) and they were assured of returns as concession tendering determined the tariffs to sell power (IRENA and GWEC, 2012). As farm sizes increased in the Concession Program, project investors could take advantage of economies of scale and helped reduce costs during the course of the diffusion stages (Qiu and Anadon, 2012).

But the uptake of rapid growth in annual installations did not occur before around 2005- the moment in which policies had covered, for the first time, the entire spectrum of investment determinants (counterparty risk and quantity-based returns were first addressed in 2005). Especially after the influential Renewable Energy Law of 2006, investors were assured that the government was taking a comprehensive regulatory 
approach to wind energy, most importantly that it was taking seriously the domestic industry's concerns over grid infrastructure, power market risks, and counterparty risks. These and other risk-related policies were complemented in the following years with a number of policies focusing on returns (mostly price-based and quantity-based), including provincial-level feed-in tariffs, international carbon trading (under Clean Development Mechanism, or CDM, which provided partial funding to $80 \%$ of the wind projects in China (Chan and Huenteler, 2015)), and eventually a nation-wide feed-in-tariff introduced in 2009.

A particular focus of Chinese policy over time has been domestic technology availability. The first demonstration project in 1986 used turbines imported from the Danish manufacturer Vestas (IRENA and GWEC, 2012; Vestas China, 2011). After that, a series of similar demonstration projects and government support for manufacturing joint ventures and imports of foreign technology brought in foreign technology to create opportunities to learn about the technology and manufacture it domestically. Starting from the early commercialization period, policies evolved to categorically incentivize projects with local technology (e.g., Ride the Wind Program in 1996). These efforts culminated in law implemented in 2003 (and phased-out in 2009) requiring (during its last phase) all wind installations to have at least $70 \%$ local components.

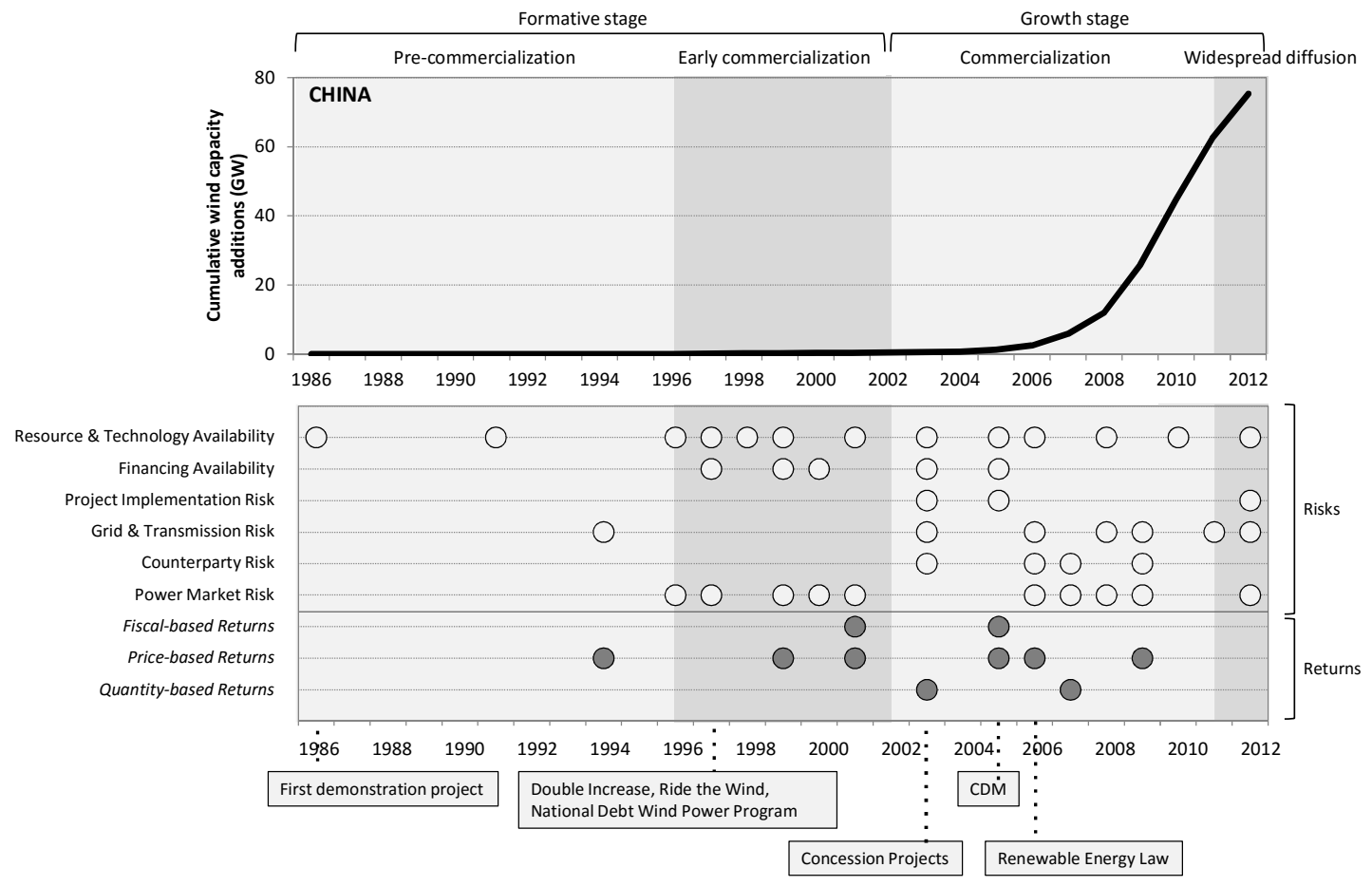

Figure 3: Evolution of public policy and investment determinants in China. In the upper chart, the black line represents three-year rolling average of the cumulative wind capacity (EIA, 2014; EPI, 2014; GWEC, 2013). The lower chart shows the investment determinants associated with different policy instruments over the diffusion stages. Policies addressing specific risks are marked in light circles; policies addressing project returns are marked in dark circles. We provide some examples of major policies beneath the graph; however, we do not make a distinction between supporting, hindering, or ambiguous policy interventions. For details on specific policies and how they are mapped to investment determinants, see Appendix B. 


\subsubsection{India}

India, too, implemented a large number of national-level wind policies over the last 30 years (at least 41 , as listed in Appendix C). Patterns in the focus of these instruments in terms of investment determinants, shown in Figure 4, suggest that India had covered a relatively broad range of investment determinants early on in the development of the sector (by 1993, 8 out of 9 investment determinants had been at least partly addressed). But after a relatively active and broadly-focused policymaking period until the end of the early commercialization in 1999, the focus of policymaking activity gradually narrowed and overall activity declined; only in the widespread diffusion period did the focus expand again.

Wind energy technology was first successfully introduced in 1986 with Danish aid for three grid-connected demonstration projects (CECL, 2006). Just like in China, early in the pre-commercialization stage, policies began to mitigate uncertainties associated with availability of technology and finance (for example, with establishment of the Indian Renewable Energy Development Agency, or IREDA in 1989), and risks related to project implementation. Early commercialization coincided with a general policy shift towards private sector participation through systemic reforms in the power sector. From this stage onwards, little attention was paid to building indigenous technological capabilities and there was no local content requirement for the installation of wind turbines.

Starting with the beginning of the commercialization stage, government activity focused narrowly on power market risks and fiscal-based returns on investment, in line with the Indian government's general emphasis on a limited role of the government in technology commercialization and private-sector competition. However, policy uncertainty sent out conflicting signals for resource mobilization-for example, the reduction of fiscal incentives (accelerated depreciation) and the introduction of the minimum alternate tax (MAT) on book value profits together acted as a disincentive for investors. As the market matured with widespread diffusion, the government attempted to further augment competition through power-sector reforms, but the focus of government policymaking also broadened compared to before as it had become clear that the wind sector was facing clear barriers to growth, including grid-integration issues and counterparty defaults. Newly introduced policies at the start of the widespread diffusion stage focused on system-integration for issues related to grid connectivity and management, and attempts were made to improve the credit capabilities of utilities, who were considered risky counterparties in power purchase agreements (PACE-D, 2013).

In terms of returns, price-based feed-in-tariffs were first introduced in 1992 (before China) to different extents by regions, but their effect was limited due to cross-subsidies in power prices that charged higher powerusage charges from industrial (non-agricultural and non-residential) customers (Mizuno, 2011). Fiscal incentives (tax holidays, accelerated depreciation) were progressively replaced by quantity-based incentives during widespread diffusion to support market competition (e.g., renewable purchase obligations), or pricebased (generation based incentive, GBI) scheme to provide returns above those from feed-in-tariffs. In the early commercialization and commercialization stages, in designing policy-induced incentives China leaned towards price incentives and India primarily towards tax incentives. 


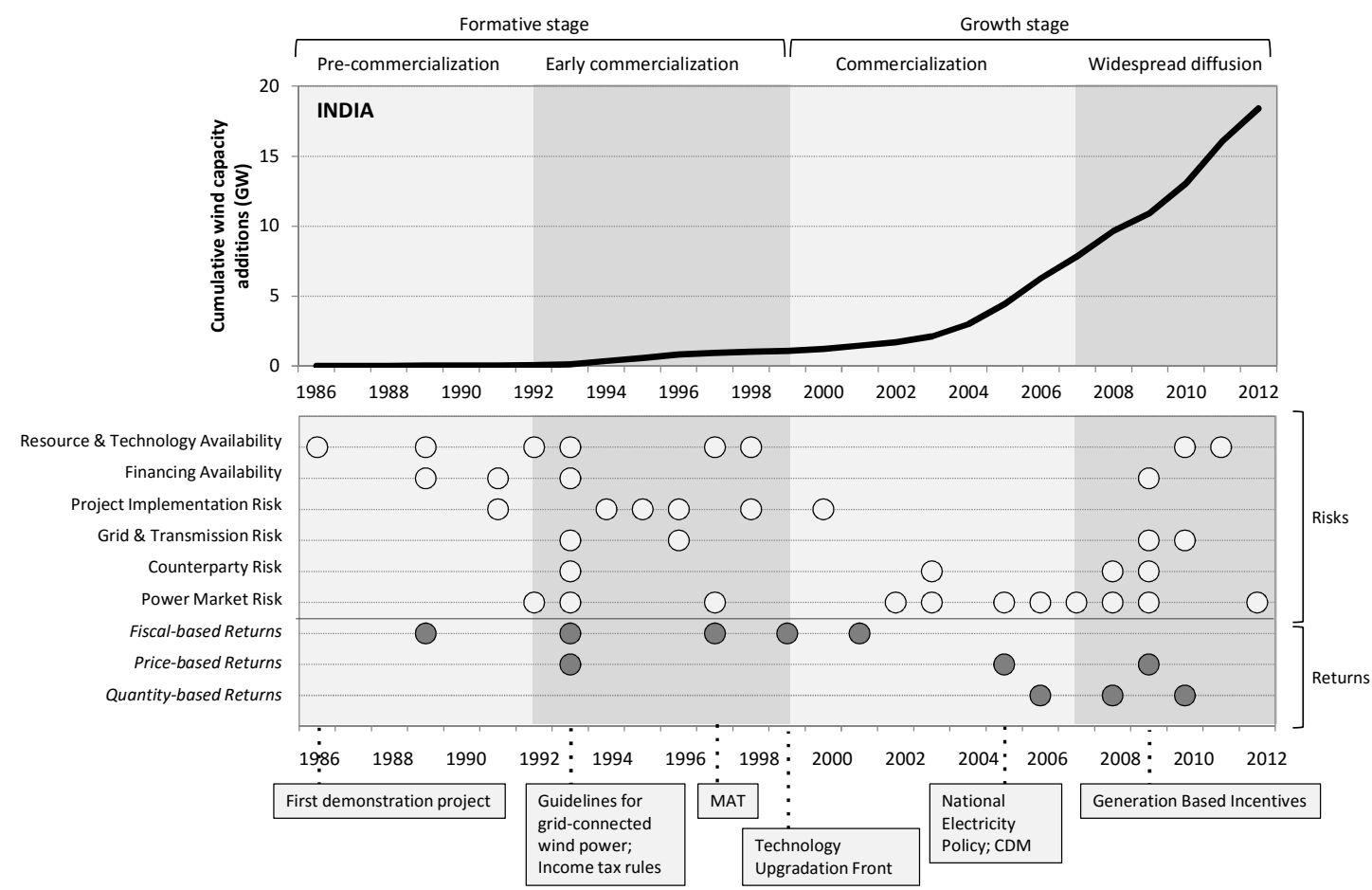

Figure 4: Evolution of public policy and investment determinants in India. In the upper chart, the black line represents three-year rolling average of the cumulative wind capacity (EIA, 2014; EPI, 2014; GWEC, 2013). The lower chart shows the investment determinants associated with different policy instruments over the diffusion stages. Policies addressing specific risks are marked in light circles; policies addressing project returns are marked in dark circles. We provide some examples of major policies underneath, however, we do not make a distinction between supporting, hindering, or ambiguous policy interventions. For details on specific policies and how they are mapped to investment determinants, see Appendix C.

\subsection{Industrial Capacity and Actor Characteristics}

The diffusion of wind energy in the two countries was driven by actors with notable differences in terms of ownership and size (the key actors are listed in Table 5). Key actors in China were mostly domestic, large, relatively homogenous firms. They were either large SOEs, or had close connections to the public sector (such as public banks). In contrast, key actors in India were smaller, heterogeneous firms, and mostly from the private sector. 


\begin{tabular}{|c|c|c|c|c|}
\hline & \multicolumn{2}{|c|}{ Formative stage } & \multicolumn{2}{|c|}{ Growth stage } \\
\hline & Pre-commercialization & Early commercialization & Commercialization & Widespread diffusion \\
\hline China & $\begin{array}{l}\text { Government-funded } \\
\text { demonstration projects; } \\
\text { Domestic investment in } \\
\text { turbine manufacturing joint } \\
\text { ventures with foreign firms, } \\
\text { but majority of turbines are } \\
\text { imported }\end{array}$ & $\begin{array}{l}\text { Power sector SOEs start } \\
\text { investing in wind farms; } \\
\text { Domestic SOEs, subsidiaries of } \\
\text { foreign turbine manufacturers } \\
\text { and joint ventures invest in } \\
\text { turbine manufacturing; } \\
\text { Chinese Development Bank } \\
\text { and other state-owned bank } \\
\text { provide loans }\end{array}$ & $\begin{array}{l}\text { Large power sector SOEs domir } \\
\text { Domestic SOEs and a few dome } \\
\text { turbine manufacturing; } \\
\text { Large state-owned grid operator } \\
\text { Chinese Development Bank and } \\
\text { provide loans }\end{array}$ & $\begin{array}{l}\text { nate wind farm investment; } \\
\text { estic private firms dominate } \\
\text { rs invest in grid integration; } \\
\text { d other state-owned bank }\end{array}$ \\
\hline India & $\begin{array}{l}\text { Government-funded } \\
\text { demonstration projects; } \\
\text { Domestic investment in } \\
\text { turbine manufacturing joint } \\
\text { ventures with foreign firms }\end{array}$ & $\begin{array}{l}\text { Small private firms from } \\
\text { outside the electricity sector } \\
\text { invest in wind farms; } \\
\text { International joint ventures } \\
\text { invest in manufacturing; } \\
\text { IREDA provides loans }\end{array}$ & $\begin{array}{l}\text { Small private firms from } \\
\text { outside the electricity sector } \\
\text { invest in wind farms; } \\
\text { Small domestic firms and local } \\
\text { subsidiaries of foreign } \\
\text { manufacturers invest in } \\
\text { manufacturing; } \\
\text { IREDA and private banks } \\
\text { provide loans }\end{array}$ & $\begin{array}{l}\text { Conventional (private-sector) } \\
\text { power generation firms start } \\
\text { investing in wind farms; } \\
\text { Domestic firms and local } \\
\text { subsidiaries of foreign } \\
\text { manufacturers invest in } \\
\text { manufacturing; } \\
\text { IREDA and private banks } \\
\text { provide loans; } \\
\text { Small SOEs and investor- } \\
\text { owned distribution utilities are } \\
\text { responsible for grid integration }\end{array}$ \\
\hline
\end{tabular}

Table 5: Key Actors Involved in Resources Mobilization in China and India in different stages of diffusion.

\subsubsection{Wind Project Owners and Developers}

The largest investments in the diffusion of wind power have to be made by the owners and developers of wind farms (we refer to them here as 'wind farm investors'). The analysis of the composition and the concentration of wind farm owners in China and India reflect contrasting features between the two countries and over time.

In China, ownership of wind farms is highly concentrated in a small set of homogenous investors, with over $90 \%$ of the market share associated with the public sector. The top five investors are large power generating companies who had over $90 \%$ of the market share in 1997 and continued to a hold a substantial market share of over 50\% in 2012 (Figure 5 and Figure 6). The decrease in concentration after the commercialization stage indicates an overall increase in the level of competition over time, yet fully private investments still represented less than $10 \%$ of installations. These large wind farm investors are mostly associated with SOEs. Private sector investment in wind projects was allowed but SOEs were in a much more favorable position to secure land, building permits, and subsidies. In the large Concession Program started in 2003, for instance, the five largest SOEs won tenders for nearly $90 \%$ of contracted wind capacity (Yu et al., 2009). 

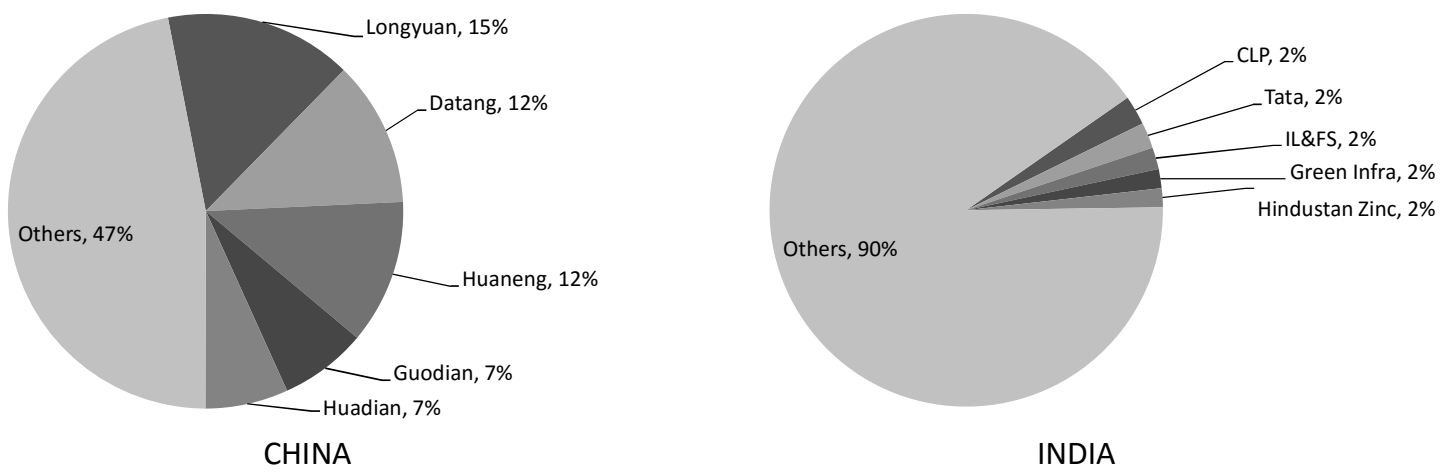

Figure 5: Market share of the top five wind-farm owners or investors for cumulative capacity installed in China and India (cumulative through 2012). Source: Own calculations from (CECL, 2013; Huaxia Wind, 2013).

In India, the private sector mobilized almost all financial resources for wind farm investments, with over $90 \%$ of the market under highly fragmented ownership throughout the four diffusion stages (Figure 6). Our dataset lists over 4,428 different owners for 23,000 wind turbines in India, compared to only 149 different owners for 57,000 turbines in China. Furthermore, investors are heterogeneous and less concentrated, with a large number of private owners with small-scale wind investments. For many investors, power generation is not the primary focus of business, exemplified by over $3 \mathrm{GW}$ of capacity-i.e., roughly $15 \%$ of all installations in India - owned by 300 textile mills in one region alone (CECL, 2013). Other investors with high tax liabilities benefited from fiscal incentives that came with the ownership of a wind turbine (Mizuno, 2007). Despite over $90 \%$ of investments through the private sector, large profit-driven independent power producers (IPPs) mainly began to participate only after the introduction of the additional policy induced incentives (GBI scheme) in 2009 (CECL, 2011).

The differences in the wind farm investors in China and India are further exemplified with the variation in the average number of turbines per owner (Figure 6). Although turbines per owner started at similar levels in both countries, the number of turbines per owner in China skyrocketed - in the 9 years of commercialization in China, there was a forty-fold increase in average number of turbines installed per owner, in contrast to only a small increase in India. 

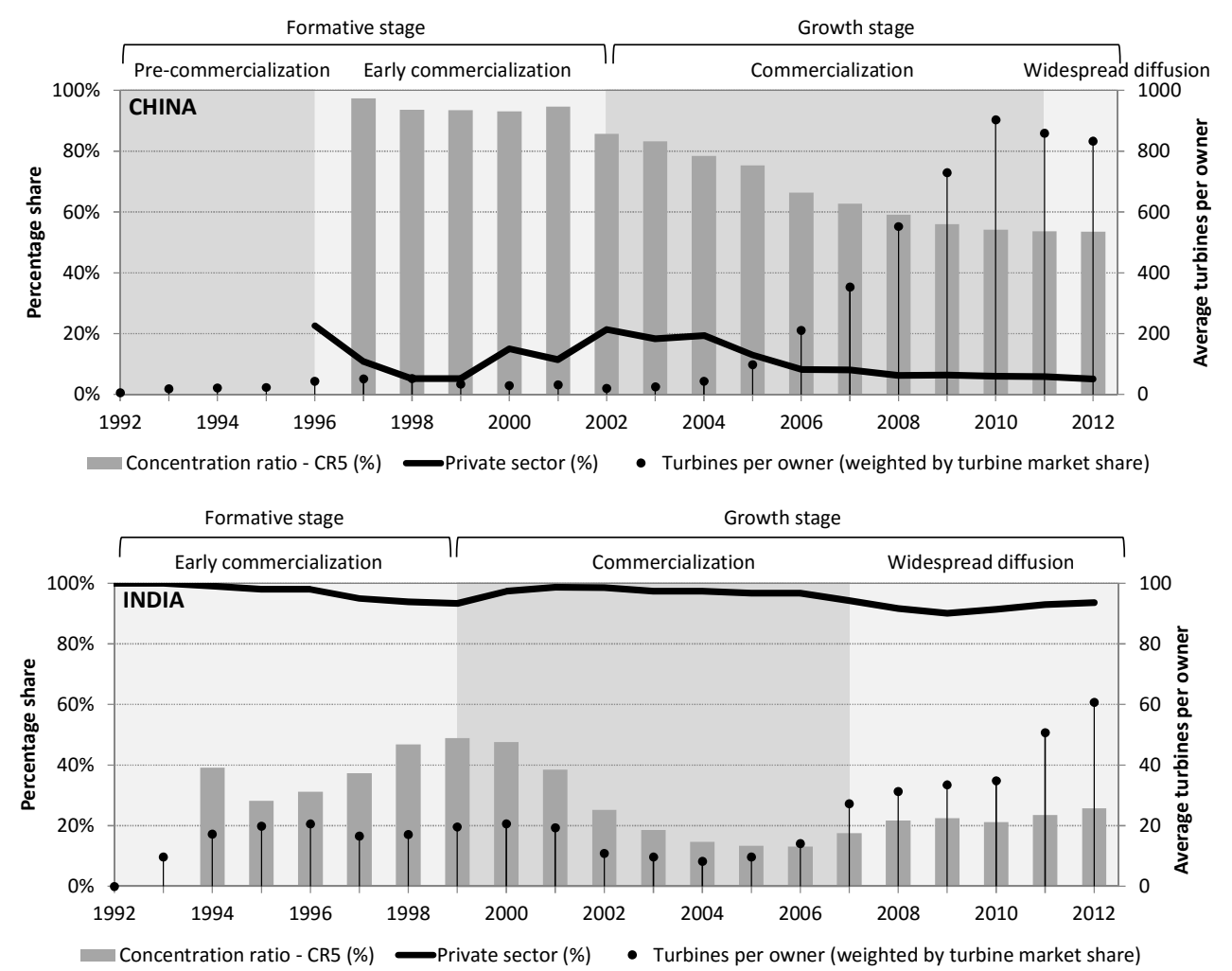

Figure 6: Composition and concentration of wind project investors. The left axis represents percentage concentration of the top five annual investors (light grey bars), and private sector investments (dark grey line) in wind energy diffusion. Investors are classified as public (i.e., SOEs and other companies where the government has a share) or fully private, after consolidating for any wholly owned subsidiaries; CR5 is the concentration ratio, or market share of the top five investors based on installed capacity. It illustrates the degree of competition and scale of investments in the market. The right axis (black dots) depicts the average turbines installed per owner annually, weighted by the owners' turbine market share. Note that the right-axis has a different scale for China and India. We used three-year rolling averages for all variables to remove fluctuations in annual data. Source: Own calculations from (CECL, 2013; Huaxia Wind, 2013).

\subsubsection{Wind Turbine Manufacturers}

The second important group of actors that have to mobilize resources during the diffusion of wind energy are turbine manufacturers. Wind turbines are large capital goods, and therefore the bulkiest components, such as towers and blades, are often manufactured locally. In 2014 , turbines cost around $\$ 1 \mathrm{mn}-\$ 10 \mathrm{mn}$ per piece, requiring manufacturers to raise large sums of working capital in addition to investments in manufacturing and logistics facilities. And although, like in many developed countries, wind farms in China and India are typically not owned by wind turbine manufacturers, manufacturers also often promote turbine demand by developing projects, securing permits, and lending to investors to whom they sell turbines (CECL, 2011).

The status and history of the local wind turbine manufacturing industries in China and India has been described elsewhere in much detail (Lewis, 2011), but three contrasting features between the two countries 
stand out. First, while in China domestically owned manufacturers dominate the market since the commercialization phase, foreign-owned companies continue to hold significant (around 40\%) market share in India, as can be seen from the market share of foreign subsidiaries, joint ventures, and domestic companies in the two countries (Figure 7). This is partly because the Chinese government promoted local manufacturing through a local-content policy (see 4.3.2). But despite withdrawal of the localization requirement in 2009, domestic companies continue to dominate the market, holding over $80 \%$ of the market share of new wind installations in 2012.

Second, while the Chinese wind turbine manufacturers are mostly (at least in part) state owned, all major Indian turbine manufacturers are privately owned. In the pre-commercialization stage of wind technology diffusion, Indian public sector agencies were involved in R\&D and turbine development (Mizuno, 2007), but this decreased after 1992 with government goals changing towards active private sector participation. Between 1986-2012, over 50 manufacturers had engaged in the Indian wind turbine sector, and 22 private domestic manufacturers provided turbines for nearly $55 \%$ of the installed wind capacity. In contrast, of the 33 manufacturers present in China, 25 were at least partly state owned, and provided turbines for nearly $80 \%$ of the installed capacity.

Third, Indian companies, in particular Suzlon, have been more successful in international competition than their Chinese counterparts. Suzlon, established in 1995, exported nearly $5 \mathrm{GW}$ of turbines between 2003 and 2011, devoting 40\% of Suzlon's production for export (Suzlon, 2012). Cumulative Chinese exports by all firms combined, in contrast, were only $0.7 \mathrm{GW}$ between 2008 and 2012, although with trends that indicate an increase in recent years (Gosens and Lu, 2014; Lema et al., 2012). 

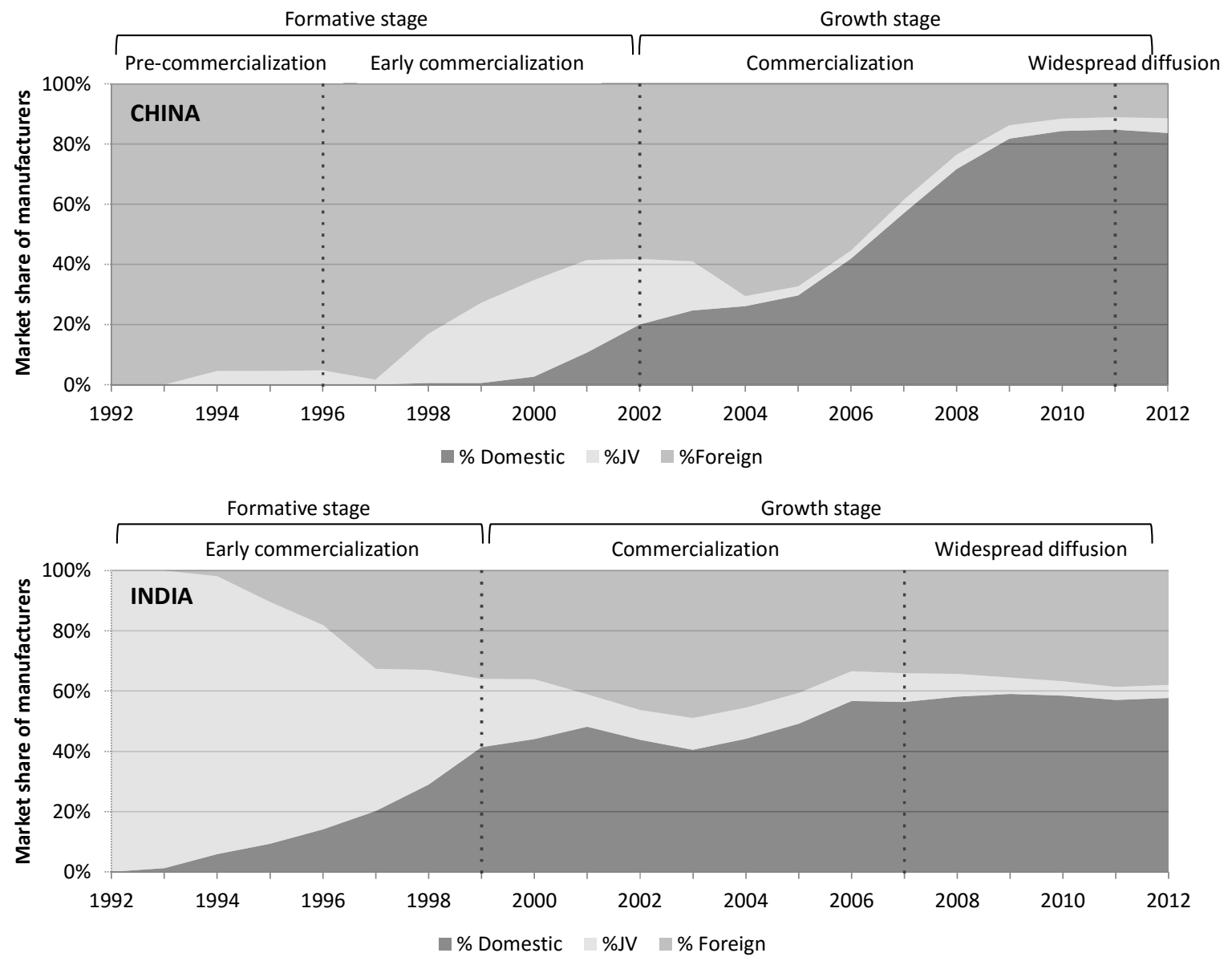

Figure 7: Market share of wind turbine capacity additions by different manufacturers. Manufacturers are classified based on technology origins as domestic (with local technology or license), joint venture (JV) between domestic and foreign company, or foreign (foreign subsidiaries and imports). We used three-year rolling averages to remove fluctuations in annual data. Source: Own calculations from (CECL, 2013; Huaxia Wind, 2013).

\subsubsection{Banks}

Financiers (such as banks) provide financial resources in the form of debt capital to wind farm investors, turbine manufacturers, grid operators, and other firms involved the in the supply chain.

In China, commercial state-owned banks provided capital for wind projects - they already had long-term relationships with existing SOEs who were historically important clients. The China Development Bank in particular provided loans at considerably lower interest rates for renewable energy projects (Spratt et al., 2014). Interest rates on loans from state-owned banks are regulated-i.e., the banks only decide if a loan gets approved, they do not set the rates themselves - and were typically around 6-8\% for wind projects (McElroy et al., 2009). In India, the government-directed IREDA (which also received extensive international funding) was chiefly active in providing debt financing for wind energy projects to private sector investors since the early commercialization stage, although at times loans took a long time to sanction, and had a short repayment 
period (CECL, 2011). While the presence of private and international banks increased in India after liberalization reforms of the 1990s, (Shrimali et al., 2013) less than a third of commercial Indian banks (including public and private) and few private equity investors were active in the renewable energy sector. In India, the cost of debt is much higher than in China and adds $24-32 \%$ to the project costs (Shrimali et al., 2013), while high exchange rates make foreign loans unattractive for investors.

\subsubsection{Grid Operators and Utilities}

Utilities and grid operators have to mobilize financing to connect and integrate wind projects to the grid. In both countries, grid operators are regulated monopolies, but in India private investors own some parts of the grid.

In China, two state-owned utilities are responsible for grid integration and transmission infrastructure-State Grid Corporation of China, and China Southern Power Grid. While they have been required to purchase all energy generated by wind farms since 2006, grid operators often lack adequate incentives to connect and integrate wind power into the grid, although wind power has practically zero marginal cost (Wu et al., 2014). In 2011, 10 TWh wind generated electricity was curtailed due to grid capacity constraints (equivalent to $13.9 \%$ of electricity actually generated through wind power); $23 \%$ of the installed turbines (corresponding to 14.5 GW of installed capacity) were not connected to the grid (Li et al., 2012).

In India, grid operators are responsible for offtake of the electricity produced and for extending the grid network. But most Indian distribution grid operators - some of which are state-owned, while others are investor-owned - have had historically poor credit ratings, and have had issues in timely payments to generators. Many Indian grid operators also had problems raising capital to invest in order to ensure compliance with policies like the Indian Electricity Grid Code (IEGC), and grid technology investments for forecasting and scheduling grid power continue to be challenging (PACE-D, 2013).

\section{Discussion}

\subsection{The Dynamics of System Building}

The diffusion patterns observed for wind energy in China and India suggest that the process of financial resource mobilization for system building (in this case power systems) in developing economies has taken well over a decade, even in a largely favorable domestic policy environment and a rapidly evolving global context. Even China, which is considered part of a second wave of wind diffusion after Denmark, Germany, and the United states, started investment in wind energy sector in the mid-1980s. The period from the first domestic technology demonstration project to the 1-GW mark of cumulative installations, which corresponds to cumulative investments in the order of $\$ 1 \mathrm{bn}-\$ 5 \mathrm{bn}$, took 19 years in China and 13 years in India. This observation is important because many global climate change mitigation scenarios assume trillions of USD of investment in low-carbon technologies in developing countries over the next 20-30 years, many of which have not yet reached even the demonstration stage (such as bioenergy with carbon-capture and storage). If compared to actual patterns of resource mobilization, these scenarios often appear over-optimistic about 
possible rates of diffusion of new technologies (Loftus et al., 2015). Now that evidence about the dynamics of technology diffusion and system building in developing countries such as the one in this paper (which indicates that the formative stages of innovation systems take time) has become available, it is important to include it to improve technology diffusion scenarios for climate mitigation.

While our analysis focused on the function of (financial) resource mobilization, the processes and investment determinants that underpin financial resource mobilization influence and are influenced by other functions of innovation. For example, the mobilization of financial resources by risk-taking entrepreneurs in India who wanted to invest in a new technology sector is strongly linked to the function of entrepreneurial activity, which is partly reflected in the actor characteristics part of the framework we present for resource mobilization in Figure 1. Similarly, the increasing availability of financing through state-owned banks along with ambitious central-government targets contributed to the function of market formation (reflected in the system outcomes part of the framework), and policies in the forms of regulations and targets (shown in the left hand side of Figure 1) contribute to the guidance of search. System-building is indeed known to be a product of the positive interactions between different functions (Suurs et al., 2010).

Our analysis further highlighted the critical role of policymakers in system building. The two countries greatly differed in the timing and intensity of resource mobilization, and we find that the timing of diffusion coincides with the timing of strong policy incentives, a correlation that is well established in the literature on the development and diffusion of low-carbon technology in industrialized countries (Nemet, 2009; Wiser et al., 2007). However, our findings further demonstrate that periods of rapid diffusion in both countries were preceded by policy activity with a particularly broad focus, addressing a wide range of investment determinants, from technology-related risks to factors relating to financing, system-integration and market pricing. This finding underpins the call for a system-perspective in policymaking targeted at technology development and diffusion.

In both cases policy and financial resource mobilization did not follow a linear stimulus-response pattern. Rather, both countries incrementally changed and adapted their regulatory framework in response to developments in system outcomes throughout the diffusion stages, indicating reactions to system functions (or imbalances). The iterative process was similar to the process of 'compulsive policymaking' for system building observed in the case of another low-carbon power source (solar energy) in a large high-income country (Germany) (Hoppmann et al., 2014). The dynamic nature of policymaking suggests a need for policy learning and adaptation, where policy interventions need to be designed to search for and react to new information on investment determinants, actor characteristics, resource mobilization efforts, and eventually, system outcomes.

Intriguingly, both countries demonstrated similar sequential changes in the most relevant investment determinants for different stages - first technology availability, then financing availability, and eventually grid and counterparty risk - despite the otherwise significant differences between the two countries' diffusion patterns (see Table 6). The existence of sequential trends in investment determinants for system building also resonate with the findings of (Suurs et al., 2010) on the prevalence of specific functions and their interactions - known as 'motors of innovation' - that drive innovation at different stages of diffusion. 
When wind turbines were first introduced in China and India with technology imported from Europe, it was important to establish technology feasibility and to build local technical capabilities to attract investors, and both governments implemented policies that addressed risks in technology availability in the push to the early commercialization stage. With the momentum of the early commercialization stage, improving availability of finance and reducing project implementation risk became important for continued investments in the sector in both countries, as large wind energy projects were capital intensive and very risky. Policies that responded to concerns over market outlook (e.g., targets set through the five-year plans) also mobilized further investments. Finally, as the market matured with widespread diffusion, there was an increasing shift towards grid integration of new wind generators, and transmission from generators to demand centers. Returns incentivized performance rather than installation, with quantity-based mechanisms designed for marketcompetition in India (e.g., renewable energy certificates), the price-based generation based incentive scheme in India, or feed-in-tariffs in China.

\begin{tabular}{|c|c|c|c|}
\hline & \multicolumn{2}{|c|}{ Formative stage } & Growth stage \\
\hline & Pre-commercialization & Early commercialization & Widespread diffusion \\
\hline $\begin{array}{l}\text { Investment } \\
\text { determinants } \\
\text { addressed by both } \\
\text { China and India }\end{array}$ & $\begin{array}{l}\text { Resource and technology } \\
\text { availability }\end{array}$ & $\begin{array}{l}\text { Financing availability } \\
\text { Project implementation risk } \\
\text { Power market risk } \\
\text { Returns (price-based in China) } \\
\text { Returns (fiscal-based in India) }\end{array}$ & $\begin{array}{c}\text { Counterparty risk } \\
\text { Grid and transmission risk } \\
\text { Returns (price- and quantity-based) }\end{array}$ \\
\hline
\end{tabular}

Table 6: Commonalities in the investment determinants addressed by policies in China and India in the different diffusion stages.

\subsection{The Interplay between Public Policies, Resource Mobilization Processes, and System Outcomes}

The commonalities described in Section 5.1 notwithstanding, China and India pursued two contrasting policy strategies to stimulate wind energy. China mobilized almost all resources through state-owned firms, while India chose to develop wind energy through the private sector, outside the established state-owned electricity companies. Contrasting approaches of policymakers and other actors in the wind energy sector is not unique to the context of these two countries. (Garud and Karnoe, 2003) analyzed the cases of Denmark and the US in their formative phase and described their approaches as 'bricolage vs. breakthrough', respectively. The interplay between policies, investment determinants, actor characteristics, and resource mobilization processes under the two contrasting strategies of China and India is summarized in Table 7. Comparing the types of investors as well as the processes and outcomes of resource mobilization under the two regimes can contribute to the understanding of renewable energy technology diffusion in developing countries, with the caveat that they are major markets and may have an intrinsic advantage in resource mobilization when compared to much smaller markets. 
In China, it took relatively long to mobilize significant financial resources, in part because it restricted foreign direct investment. Once the main barriers were overcome, the network of SOEs along the supply chain was able to move extremely fast, but resources were not always allocated in the most efficient way. At the beginning, the formative period was characterized by very little commercial investment. The government restricted foreign direct investment by foreign wind farm investors and foreign turbine manufacturers, and, despite a growing number of government initiatives to address risks and returns since the mid-1990s, the interest by the local industry to invest in the risky wind business was limited. This situation changed fundamentally in the early to mid-2000s. Driven by a comprehensive legislative framework (most notably the Renewable Energy Law in 2006), ambitious central-government targets, and generous subsidies, a large number of the SOEs in wind farm development and turbine manufacturing were able to mobilize financial resources at an unprecedented pace. State-owned wind farm investors were able to move rapidly by capitalizing on existing relationships with state-owned banks and provincial governments, substantially reducing project development risks. Turbine manufacturers were able to rapidly expand production and achieve economies of scale due to protectionist policies and full order books. The latter was often enabled by semi-formal relationships with individual wind farm investors. For example, China's Guodian group is a large SOE and one of the largest wind farm investors in the country. Another large wind farm investor, Longyuan, and the wind turbine manufacturer United Power are both subsidiaries of the Guodian group. As of 2011, 59.5\% of the turbine market share was attributed to such connections (Gosens and Lu, 2014). These stable user-producer relationships helped reduce investment costs, making wind energy even more attractive (Tang and Popp, 2014). However, while the network of semi-formal relationships between SOEs across the supply chain helped raise substantial amounts of capital in a very short time, it also lead to inefficient resource allocation. Eventually, the rate of growth of installed wind farm capacity in China slowed down substantially in 2010 due to a combination of factors that have yet to be systematically analyzed and quantified: turbine manufacturers over-invested in manufacturing capacity; turbine manufacturers typically produced turbines of lower quality and could not compete with international turbines in some Chinese projects; many wind farms were not connected to the grid; and significant amounts of generated power was curtailed due to inefficient grid management practices.

India focused on private sector participation and liberalization of the wind sector from the onset. This led to more volatile and profit-driven diffusion, but also to more competitive wind development and manufacturing industries with more efficient resource allocation. Policies created conditions for significant commerciallyoriented investment and experimentation already in the early-commercialization stages, with many new entrants into the wind farm ownership business as well as domestic and international private companies that set up manufacturing joint ventures in India. Many investors in wind farms were small-scale enterprises operating in textiles that needed captive power from wind turbines for their own energy-intensive manufacturing industry in face of frequent power cuts. Because they faced high opportunity cost from power cuts, the profit expectations of these small investors were typically much smaller than for large companies focused on power generation (Spratt et al., 2014), enabling growth early on in the formative stage of diffusion. The policies of the formative period thus resulted in a large number of private investors with small-scale investment capacity. But the small-scale investments, along with some policy uncertainty, made it difficult to reach a critical mass necessary for stable diffusion, resulting in a slower, volatile growth. In the growth period, too, the large number of small investors, who were more interested generating energy for their normal 
business than in selling large amounts of power to the grid, created barriers to large-scale wind farms and rapid growth in mobilized financial resources. To fill in this gap, the rising domestic manufacturing industry began to act as project developers who operated wind farms, with turbines owned by small investors. At least for one company (Suzlon) the competitive market for wind turbines in India—where protectionist policies were much less pursued than China - provided an environment to grow into a globally successful turbine supplier. In the widespread diffusion stage, policies began to also attract large-scale financial resources from large independent power producers who primarily focused on generating profits from selling power to the grid. And although local distribution grid operators often have problems in raising capital to smoothen grid integration, grid connection and curtailment are much smaller issues in India than in China.

\begin{tabular}{|c|c|c|c|c|}
\hline & \multicolumn{2}{|c|}{ Formative stage } & \multicolumn{2}{|c|}{ Growth stage } \\
\hline & Pre-commercialization & Early commercialization & Commercialization & Widespread diffusion \\
\hline China & $\begin{array}{l}\text { Government policies addressed } \\
\text { only a few investment } \\
\text { determinants; This resulted in } \\
\text { slow resource mobilization, } \\
\text { mostly in the form of pre- } \\
\text { commercial wind farms, R\&D, } \\
\text { and government-directed } \\
\text { manufacturing joint ventures with } \\
\text { local SOEs }\end{array}$ & $\begin{array}{l}\text { Government policies addressed } \\
\text { an increasing number of } \\
\text { investment determinants; This } \\
\text { attracted investment from the first } \\
\text { commercially-oriented domestic } \\
\text { wind farm investors and foreign } \\
\text { joint ventures with local turbine } \\
\text { manufacturers }\end{array}$ & $\begin{array}{l}\text { Government policies covered the } \\
\text { full range of investment } \\
\text { determinants, placed ambitious } \\
\text { targets set at the national level, } \\
\text { were protectionist; This provided } \\
\text { incentives for many large SOEs } \\
\text { to invest in wind farms and } \\
\text { manufacturing; well-connected } \\
\text { SOEs were able to mobilize } \\
\text { resources at unparalleled speed } \\
\text { and scale, but domestic turbine } \\
\text { quality from SOEs suffered }\end{array}$ & $\begin{array}{l}\text { Government policies covered few } \\
\text { investment determinants; This } \\
\text { slowed down growth as } \\
\text { inefficiencies in resource } \\
\text { allocation were revealed, in } \\
\text { particular with regard to } \\
\text { overcapacity in wind turbine } \\
\text { manufacturing, wind farms that } \\
\text { were not connected to the grid } \\
\text { and major problems in grid } \\
\text { management }\end{array}$ \\
\hline India & $\begin{array}{l}\text { Government policies addressed a } \\
\text { number of investment } \\
\text { determinants early on; This } \\
\text { attracted early private investment } \\
\text { in highly subsidized pre- } \\
\text { commercial wind farms and } \\
\text { international manufacturing joint } \\
\text { ventures }\end{array}$ & $\begin{array}{l}\text { Government policies covered a } \\
\text { wide range of investment } \\
\text { determinants; This attracted } \\
\text { considerable growth in early } \\
\text { commercial investment in wind } \\
\text { farms, mostly by small, non- } \\
\text { traditional private investors and } \\
\text { new domestic manufacturers; but } \\
\text { soon unstable policy environment } \\
\text { led to decline in investment }\end{array}$ & $\begin{array}{l}\text { Government policies focused } \\
\text { narrowly on power market risks } \\
\text { and returns; This facilitated } \\
\text { competitive private-sector } \\
\text { investment in wind farms and } \\
\text { manufacturing to mobilize } \\
\text { resources at stable but moderate } \\
\text { rate; one privately-owned } \\
\text { manufacturer, Suzlon, became } \\
\text { globally competitive }\end{array}$ & $\begin{array}{l}\text { Government broadened focus of } \\
\text { policymaking to wider range of } \\
\text { investment determinants; This } \\
\text { allowed for investment by private } \\
\text { sector to stabilize at relatively } \\
\text { high levels; grid integration is in } \\
\text { some areas hindered by } \\
\text { insufficient capitalization of } \\
\text { distribution utilities }\end{array}$ \\
\hline
\end{tabular}

Table 7: Stylized interplay between public policies, investment determinants, actor characteristics, and financial resource mobilization in China and India along different diffusion stages.

\subsection{Trade-offs for Public Policy in Innovation-System Building}

We have shown that public policies were crucial in changing investment determinants and attracting financial resources to the wind power sector. But the interplay between policy approaches, resource mobilization processes, and system outcomes observed in China and India suggests that developing countries governments face three main trade-offs in building technological innovation systems.

\section{a) The role of the state in financial resource mobilization}

Power sectors in developing countries are often partly reformed with hybrid ownership from the public and the private sectors. When aiming to promote the diffusion of new technologies, governments therefore face the choice between opening up investment to more nimble private actors or to develop the technology within the public sector. Our analysis suggests that this entails a trade-off between three 
factors: the ability to attract experimentation, the ability to mobilize resources, and the ability to allocate resources efficiently. India's private sector strategy led to earlier experimentation in terms of the technology developed, the types of actors involved, and the business models used, and arguably led to more efficient resource allocation, whereas resource mobilization was much less effective than in China. Although the observed differences are strongly influenced by the domestic political economy of the two countries (for example, China's investment occurred under a more stable policy environment with a longer time-horizon), they are in line with theoretical expectations about the strengths and weaknesses of the public and private sectors.

\section{b) The timing of financial resource mobilization}

Governments face the choice of when to start encouraging the deployment of a new technology. Moving early may bring early mover advantages, while latecomers can draw on global experiences. India pushed early for takeoff and commercialization and is now home to a globally successful wind turbine manufacturer. However, in part due to limited local experience with wind energy and a power sector that was not working effectively, diffusion of wind energy was more erratic, and a dedicated industry of wind farm developers only developed late in the process. China, in contrast, could draw on experience from a more established global wind energy industry, installed more advanced turbines, and was still successful in nurturing a broader homegrown industry of developers and manufacturers, at least for the domestic market.

Countries with governments that want to promote the diffusion of clean energy technologies will find themselves in a situation that is different from that of wind energy diffusion in China or India. On the one hand, relatively well-established industries such as wind have evolved in terms of their structure, scale, and cost since China's massive investment push in the last decade. The experiences of China and India can now be thought of as a second wave of global industry development, trailing the first wave of distinct domestic approaches followed by pioneering countries like Denmark, Germany, and the USA (Garud and Karnoe, 2003). Other developing countries, such as Indonesia and Morocco, that are now pursuing the diffusion of wind power could be considered as a third wave of global industry growth, as understood within the evolving dynamics of the global wind energy sector. On the other hand, industries around technologies such as bioenergy with carbon-carbon capture and storage are still at a relatively early demonstration stage. The timing and choice of policies should thus depend on the type of technology, the national context, and capabilities, as well as the global development of the industry.

\section{c) Domestic versus foreign resources}

Lastly, governments also face the choice between attracting foreign technology and capital, and encouraging investment from domestic companies (e.g., from related sectors). Large incoming international capital flows attracted by the opportunities in emerging markets often come with knowhow and may facilitate technology transfer, but this investment aimed at the local market also resulted in a local focus of knowledge of domestic manufacturers. China achieved a very high share of local 
value creation along the supply chain through relatively protective policies, first forcing foreign firms into joint ventures and then restricting imports through aggressive local-content requirements. Foreign firms did transfer technology, especially through licenses, providing a starting point for learning and innovation for local manufacturers (Ru et al., 2012). But the licenses were often for outdated turbine models and, with a primary focus on catering to local demand; manufacturers had limited exposure to international requirements and few exports. In contrast, the liberalized market in India allowed for greater competition between foreign subsidiaries and domestic manufacturers. This competitive environment, in combination with the early market entry into the wind sector contributed to international competitiveness and substantial exports from at least one domestic supplier (i.e., Suzlon). While the emergence of one internationally active supplier in India was also likely affected by unpredictable factors (e.g., the right person had the right idea at the right time), at least part of such an outcome can be attributed to the competitive demands set by the policy environment that encouraged entrepreneurial activity.

\section{Conclusions}

In this paper, we analyzed the process of financial resource mobilization in technological innovation systems (TIS) in two large developing countries. In particular, we assessed the interplay of policy interventions, investment determinants, and actor characteristics that enabled the large-scale diffusion of wind energy technology in the period 1986-2012 in China and India, two countries that will play a major role in climate change mitigation over the coming decades. Our findings contribute to the literature on technological innovation and diffusion in developing countries in three main ways.

First, we shed light on the mechanisms that enable financial resource mobilization in an innovation system. We find that both China and India were able to mobilize significant financial resources for investment in wind energy technology in a diffusion process that lasted more than two decades, going through distinct stages of pre-commercialization, early commercialization, commercialization, and widespread diffusion. Our analysis reveals how transitions between these stages were enabled by an interplay of public policies and a set of nine investment determinants, conditioned by each country's political economy, thus providing a framework for future analyses of resource mobilization in TIS. Better understanding the dynamic interplay between policy support and investment determinants and its impact on actors will allow for an evaluation of the impact of different policy instruments on resource-mobilization efforts by different actors and to derive more detailed policy implications.

Second, we identified patterns in the sequence in which China and India addressed the different investment determinants, starting with technology availability, then financing availability, and eventually systemintegration and counterparty risk. This indicates that the mechanisms that enable resource mobilization and the most important investment determinants change over time, depending on the stage of diffusion. The interplay between policy instruments and investment determinants means that governments need to adapt their policy support schemes over time, and ideally integrate the necessary flexibility and sunset clauses to allow the introduction of changes resulting from the intermediate learning from the start. By identifying these 
patterns, we contribute to a richer understanding on the dynamic aspects of TIS. Future research, possibly using our taxonomy of investment determinants, needs to further explore these dynamics in the mechanisms of resource mobilization.

Third, we identified three trade-offs that a government faces when aiming to stimulate diffusion of new energy technologies: (i) between promotion of investment in state-owned enterprises, which may be able to raise resources more swiftly, and the private sector, which may be more willing to experiment and may allocate mobilized resources more efficiently; (ii) between moving early to promote growth (large-scale diffusion) to capitalize on first-mover advantages, and moving late to capitalize on global experience; and (iii) between attracting foreign investment to provide a competitive environment, and protecting local industry to maintain a higher share of local value creation. We pointed out that China and India pursued two contrasting policy strategies to stimulate wind energy. Resource mobilization in China was much more rapid, enabled through more direct government control of the (state-owned) investors and relatively low-cost technology supplied by a large domestic manufacturing industry that has difficulties competing in the global market. In contrast, India chose to develop wind energy through the private sector instead of through the existing (state-owned) electric utilities, and created a highly competitive market for wind turbines, which led to more modest growth but the emergence of one internationally competitive manufacturing firm. Both strategies had their merits and drawbacks, and there seems to be no 'silver bullet', but it is clear that they led to distinct system outcomes in the countries. This suggests that, besides the (rate of) mobilization of resources, the outcomes of technological innovation systems are affected by the allocation of resources - in particular, if policies promote resource allocation by private or public-sector actors. Given the important role of publicly-owned companies across the developing world, researchers analyzing innovation systems in emerging economies need to pay at least as much attention to how resources are allocated as to the extent to which they are mobilized.

Our analysis has two major limitations. First, we relied on a mostly qualitative and descriptive methodology to analyze investment determinants and investment outcomes. Quantifying the impact of each individual policy intervention on all possible metrics for success (e.g., domestic patents, licenses, jobs created, environmental benefits, health benefits, patents, etc.) was beyond the scope of this paper, pointing toward a promising avenue for future research that will have to deal with the problems of policies often acting simultaneously. Second, investment determinants are also affected by factors outside the domestic wind sector or national-level policies, including regional policies and trends, macroeconomic developments, changes in electricity prices, and wind-sector developments in other countries. While the commonalities, differences, and trade-offs identified in this paper hold, given the increasingly global nature of the renewable energy industry, a better understanding of the global linkages in the Chinese and Indian innovation systems for wind energy will be needed to provide adequate policy advice to countries that consider investing in wind power in the future.

\section{Bibliography}

Bardhan, P.K., 2010. Awakening Giants, Feet of Clay. Princeton University Press. 
Batlle, C., Pérez-Arriaga, I.J., Zambrano-Barragán, P., 2012. Regulatory design for RES-E support mechanisms: Learning curves, market structure, and burden-sharing. Energy Policy 41, 212-220.

Bergek, A., Jacobsson, S., Carlsson, B., Lindmark, S., Rickne, A., 2008. Analyzing the functional dynamics of technological innovation systems: A scheme of analysis. Research Policy 37, 407-429. doi:10.1016/j.respol.2007.12.003

Bergek, A., Mignon, I., Sundberg, G., 2013. Who invests in renewable electricity production? Empirical evidence and suggestions for further research. Energy Policy 1-14. doi:10.1016/j.enpol.2013.01.038

Bhattacharyya, S.C., 2013. Financing energy access and off-grid electrification: A review of status, options and challenges. Renewable and Sustainable Energy Reviews 20, 462-472. doi:10.1016/j.rser.2012.12.008

Binz, C., Truffer, B., Coenen, L., 2014. Why space matters in technological innovation systems-Mapping global knowledge dynamics of membrane bioreactor technology. Research Policy 43, 138-155. doi:10.1016/j.respol.2013.07.002

Blum, N.U., Bening, C.R., Schmidt, T.S., 2015. An analysis of remote electric mini-grids in Laos using the Technological Innovation Systems approach. Technological Forecasting and Social Change. doi:10.1016/j.techfore.2015.02.002

Boden, T., Andres, B., Marland, G., 2013. Global, Regional, and National Fossil-Fuel CO2 Emissions. Carbon Dioxide Information Analysis Center, Oak Ridge National Laboratory, U.S. Department of Energy, Oak Ridge, Tenn., U.S.A. doi:10.3334/CDIAC/00001_V2013

BTM Consult, 2013.

CECL, 2013. Indian Wind Power Directory. Consolidated Energy Consultants Limited.

CECL, 2011. Assessment of Investment Climate for Wind Power Development in India for Indian Renewable Energy Development Agency (IREDA) - New Delhi. Consolidated Energy Consultants Limited.

CECL, 2006. Indian Wind Power Directory. Consolidated Energy Consultants Limited.

Chan, G., Huenteler, J., 2015. Financing wind energy deployment in China through the Clean Development Mechanism: Additionality and incentives for technological change, in: Chan, G. "Essays on Energy Technology Innovation Policy”, Ph.D. Dissertation. Harvard Kennedy School.

Coenen, L., Benneworth, P., Truffer, B., 2012. Toward a spatial perspective on sustainability transitions. Research Policy, Special Section on Sustainability Transitions 41, 968-979. doi:10.1016/j.respol.2012.02.014

Dahlman, C., 2007. Technology, globalization, and international competitiveness: Challenges for developing countries, in: Industrial Development for the 21st Century: Sustainable Development Perspectives. p. 29.

Dai, Y., Xue, L., 2014. China's policy initiatives for the development of wind energy technology. Climate Policy 0, 1-28. doi:10.1080/14693062.2014.863549

EIA, 2014. International Energy Statistics. US Energy Information Administration (EIA), Washington, DC, available online at http://www.eia.gov/.

EPI, 2014. Earth Policy Institute [WWW Document]. Earth Policy Institute - Data Center. URL http://www.earth-policy.org/

Farla, J., Markard, J., Raven, R., Coenen, L., 2012. Sustainability transitions in the making: A closer look at actors, strategies and resources. Technological Forecasting and Social Change, Contains Special Section: Actors, Strategies and Resources in Sustainability Transitions 79, 991-998. doi:10.1016/j.techfore.2012.02.001

Frankfurt School-UNEP Centre/BNEF, 2014. Global Trends in Renewable Energy Investment 2014. Frankfurt am Main.

Friebe, C.A., von Flotow, P., Täube, F.A., 2014. Exploring technology diffusion in emerging markets - the role of public policy for wind energy. Energy Policy 70, 217-226. doi:10.1016/j.enpol.2014.03.016

Frisari, G., Stadelmann, M., 2015. De-risking concentrated solar power in emerging markets: The role of policies and international finance institutions. Energy Policy 82, 12-22. doi:10.1016/j.enpol.2015.02.011

Ganesan, K., Choudhury, P., Palakshappa, R., Jain, R., Raje, S., 2014. Assessing Green Industrial Policy The India experience. Council on Energy, Environment and Water (CEEW) and International Institute for Sustainable Development (IISD). 
Garud, R., Karnoe, P., 2003. Bricolage versus breakthrough: distributed and embedded agency in technology entrepreneurship. Research Policy, Special Issue on Technology Entrepreneurship and Contact Information for corresponding authors 32, 277-300. doi:10.1016/S0048-7333(02)00100-2

Geels, F.W., 2005. Processes and patterns in transitions and system innovations: Refining the co-evolutionary multi-level perspective. Technological Forecasting and Social Change 72, 681-696. doi:10.1016/j.techfore.2004.08.014

Gosens, J., Lu, Y., 2014. Prospects for global market expansion of China's wind turbine manufacturing industry. Energy Policy 1-18. doi:10.1016/j.enpol.2013.12.055

Gosens, J., Lu, Y., 2013. From lagging to leading? Technological innovation systems in emerging economies and the case of Chinese wind power. Energy Policy 60, 234-250. doi:10.1016/j.enpol.2013.05.027

GWEC, 2013. Global Wind Report - Annual Market Update 2012. Global Wind Energy Council.

GWEC, 2012. India Wind Energy Outlook - 2012. Global Wind Energy Council.

Hekkert, M.P., Suurs, R.A.A., Negro, S.O., Kuhlmann, S., Smits, R.E.H.M., 2007. Functions of innovation systems: A new approach for analysing technological change. Technological Forecasting and Social Change 74, 413-432. doi:10.1016/j.techfore.2006.03.002

Hoppmann, J., Huenteler, J., Girod, B., 2014. Compulsive policy-making-The evolution of the German feed-in tariff system for solar photovoltaic power. Research Policy 43, 1422-1441. doi:10.1016/j.respol.2014.01.014

Huaxia Wind, 2013. Huaxia Wind Database.

Huenteler, J., 2014. International support for feed-in tariffs in developing countries-A review and analysis of proposed mechanisms. Renewable and Sustainable Energy Reviews 39, 857-873. doi:10.1016/j.rser.2014.07.124

IEA, 2014. World Energy Investment Outlook. International Energy Agency, Paris, France.

IRENA, 2012. Wind Power. Renewable Energy Technologies: Cost Analysis Series, IRENA Working Paper 1: Power Sector.

IRENA, GWEC, 2012. 30 Years of Policies for Wind Energy - Lessons from 12 Wind Energy Markets.

Jacobsson, S., Lauber, V., 2006. The politics and policy of energy system transformation - explaining the German diffusion of renewable energy technology. Energy Policy 34, 256 - 276. doi:http://dx.doi.org/10.1016/j.enpol.2004.08.029

Jakob, M., Steckel, J.C., Klasen, S., Lay, J., Grunewald, N., Martínez-Zarzoso, I., Renner, S., Edenhofer, O., 2014. Feasible mitigation actions in developing countries. Nature Climate Change 4, 961-968. doi:10.1038/nclimate2370

Jolly, S., Raven, R., 2013. Collective institutional entrepreneurship and contestations in wind energy in India. Eindhoven Center for Innovation Studies (ECIS).

Justice, S., 2009. Private Financing of Renewable Energy - A Guide for Policymakers. Renewable Energy Finance Project, Chatham House; Bloomberg New Energy Finance; and the UNEP Sustainable Energy Finance Initiative.

Karltorp, K., 2014. SCALING UP RENEWABLE ENERGY TECHNOLOGIES-The role of resource mobilisation in the growth of technological innovation systems. Chalmers University of Technology.

Khanna, T., Palepu, K.G., 1997. Why focused strategies may be wrong for emerging markets. Harvard Business Review.

Khanna, T., Palepu, K.G., Sinha, J., 2005. Strategies that fit emerging markets. Harvard Business Review 83, 4-19.

Lema, R., Berger, A., Hubert, S., 2012. China's impact on the global wind power industry (No. Discussion Paper 16/2012). German Development Institute / Deutsches Institut für Entwicklungspolitik (DIE), Bonn.

Lewis, J.I., 2012. Green Innovation in China: China's Wind Power Industry and the Global Transition to a Low-Carbon Economy. Columbia University Press.

Lewis, J.I., 2011. Building a national wind turbine industry: experiences from China, India and South Korea. International Journal of Technology and Globalisation 5, 281-305.

Lewis, J.I., Wiser, R.H., 2007. Fostering a renewable energy technology industry: An international comparison of wind industry policy support mechanisms. Energy Policy 35, 1844-1857. doi:10.1016/j.enpol.2006.06.005 
Li, H., Meng, L., Wang, Q., Zhou, L.-A., 2008. Political connections, financing and firm performance: Evidence from Chinese private firms. Journal of Development Economics 87, 283-299. doi:10.1016/j.jdeveco.2007.03.001

Li, J., Xie, H., Tang, W., Cai, F., Gao, H., Wang, W., Qiao, L., Yang, X., Li, X., 2012. 2012 China wind energy outlook. Chinese Renewable Energy Industries Association-Global Wind Energy Council-Greenpeace.

Loftus, P.J., Cohen, A.M., Long, J.C.S., Jenkins, J.D., 2015. A critical review of global decarbonization scenarios: what do they tell us about feasibility? WIREs Clim Change 6, 93-112. doi:10.1002/wcc. 324

McElroy, M.B., Lu, X., Nielsen, C.P., Wang, Y., 2009. Potential for Wind-Generated Electricity in China. Science 325, 1378-1380. doi:10.1126/science.1175706

Mizuno, E., 2011. Enabling environment and policy principles for replicable technology transfer: Lessons from wind energy in India. Diffusion of renewable energy technologies 33.

Mizuno, E., 2007. Cross-border Transfer of Climate Change Mitigation Technologies: The Case of Wind Energy from Denmark and Germany to India.

MNRE, 2015. Proposed National Wind Energy Mission. Ministry of New and Renewable Energy (MNRE), New Delhi, India.

Musiolik, J., Markard, J., Hekkert, M., 2012. Networks and network resources in technological innovation systems: Towards a conceptual framework for system building. Technological Forecasting and Social Change, Contains Special Section: Actors, Strategies and Resources in Sustainability Transitions 79, 1032-1048. doi:10.1016/j.techfore.2012.01.003

NDRC, 2015. China's 13th Five Year Plan (2016-2020). National Development and Reform Commission (NDRC), Beijing, China.

Nemet, G.F., 2009. Demand-pull, technology-push, and government-led incentives for non-incremental technical change. Research Policy 38, 700-709.

Ohara, M., Vijayabaskar, M., Lin, H., 2011. Industrial Dynamics in China and India. Palgrave Macmillan.

PACE-D, 2013. Financing Renewable Energy in India: A review of current status and recommendations for innovative mechanisms, Partnership to Advance Clean Energy - Deployment (PACE - D) - Technical Assistance Program.

Qiu, Y., Anadon, L.D., 2012. The price of wind power in China during its expansion: Technology adoption, learning-by-doing, economies of scale, and manufacturing localization. Energy Economics 34, 772785. doi:10.1016/j.eneco.2011.06.008

Rodrik, D., 2009. One economics, many recipes: globalization, institutions, and economic growth. Princeton University Press.

Rodrik, D., Subramanian, A., 2004. FROM "HINDU GROWTH" TO PRODUCTIVITY SURGE: THE MYSTERY OF THE INDIAN GROWTH TRANSITION. NBER Working Paper Series.

Ru, P., Zhi, Q., Zhang, F., Zhong, X., Li, J., Su, J., 2012. Behind the development of technology: The transition of innovation modes in China's wind turbine manufacturing industry. Energy Policy 1-12. doi:10.1016/j.enpol.2011.12.025

Schmidt, T.S., 2014. Low-carbon investment risks and de-risking. Nature Climate Change 4, 237-239.

Shrimali, G., Nelson, D., Goel, S., Konda, C., Kumar, R., 2013. Renewable deployment in India: Financing costs and implications for policy. Energy Policy 1-16. doi:10.1016/j.enpol.2013.07.071

Spratt, S., Dong, W., Krishna, C., Sagar, A.D., Qi, Y., 2014. What Drives Wind and Solar Energy Investment in India and China? Institute of Development Studies.

Suurs, R.A.A., Hekkert, M.P., Kieboom, S., Smits, R.E.H.M., 2010. Understanding the formative stage of technological innovation system development: The case of natural gas as an automotive fuel. Energy Policy 38, 419-431. doi:10.1016/j.enpol.2009.09.032

Suzlon, 2012. Suzlon Annual Reports 2004 - 2013. Suzlon.

Tang, T., Popp, D., 2014. The Learning Process and Technological Change in Wind Power: Evidence from China's CDM Wind Projects. NBER Working Paper Series 0-47.

The World Bank, 2013. Country and Lending Groups | Data [WWW Document]. URL http://data.worldbank.org/about/country-and-lending-groups (accessed 5.15.15). 
UNEP, SEFI, SEF, 2008. Public Finance Mechanisms to Mobilize Investment in Climate Change Mitigation $1-40$.

Vestas China, 2011. Vestas returns to Hainan province with a new order for 48 MW. News Release No. $8 / 2011$

Waissbein, O., Glemarec, Y., Bayraktar, H., Schmidt, T.S., 2013. Derisking Renewable Energy Investment. A Framework to Support Policymakers in Selecting Public Instruments to Promote Renewable Energy Investment in Developing Countries. United Nations Development Programme (UNDP), New York, NY.

Wiser, R.H., Bolinger, M., Barbose, G.L., 2007. Using the Federal Production Tax Credit to Build a Durable Market for Wind Power in the United States. Lawrence Berkeley National Laboratory.

Wüstenhagen, R., Menichetti, E., 2012. Strategic choices for renewable energy investment: Conceptual framework and opportunities for further research. Energy Policy 40, 1-10. doi:10.1016/j.enpol.2011.06.050

Wu, Z., Sun, H., Du, Y., 2014. A large amount of idle capacity under rapid expansion: Policy analysis on the dilemma of wind power utilization in China. Renewable and Sustainable Energy Reviews 32, 271277. doi:10.1016/j.rser.2014.01.022

Yu, J., Ji, F., Zhang, L., Chen, Y., 2009. An over painted oriental arts: Evaluation of the development of the Chinese renewable energy market using the wind power market as a model. Energy Policy 37, 52215225. doi:10.1016/j.enpol.2009.07.035 
Appendix A: Ranking of countries by cumulative capacity of wind energy (GWEC, 2013), and the share of wind in total installed capacity and generation (EIA, 2014). Note: The share of electricity generated from renewable energy is typically lower than the share of installed capacity due to their lower capacity factors as compared to fossil fuels.

\begin{tabular}{|c|c|c|c|c|c|}
\hline Ranking & Country & $\begin{array}{c}\text { Cumulative Wind } \\
\text { Capacity in } 2012 \\
\text { (GW) }\end{array}$ & $\begin{array}{c}\text { Cumulative } \\
\text { Wind Capacity } \\
\text { in } 2011(\mathrm{GW})\end{array}$ & $\begin{array}{c}\text { Share of Wind in } \\
\text { Total Capacity in } \\
2011(\%)\end{array}$ & $\begin{array}{c}\text { Share of Wind in } \\
\text { Total Generation in } \\
2011(\%)\end{array}$ \\
\hline 1 & China & 75.3 & 62.4 & $6 \%$ & $2 \%$ \\
\hline 2 & U.S. & 60.0 & 46.0 & $4 \%$ & $3 \%$ \\
\hline 3 & Germany & 31.3 & 29.1 & $18 \%$ & $8 \%$ \\
\hline 4 & Spain & 22.8 & 21.7 & $21 \%$ & $15 \%$ \\
\hline 5 & India & 18.4 & 16.1 & $7 \%$ & $3 \%$ \\
\hline 6 & U.K. & 8.6 & 6.6 & $7 \%$ & $5 \%$ \\
\hline 7 & Italy & 8.1 & 6.9 & $6 \%$ & $4 \%$ \\
\hline 8 & France & 7.6 & 6.8 & $5 \%$ & $2 \%$ \\
\hline 9 & Canada & 6.2 & 5.3 & $4 \%$ & $3 \%$ \\
\hline \multirow[t]{2}{*}{10} & Denmark & 4.1 & 4.0 & $29 \%$ & $29 \%$ \\
\hline & World & 283.2 & 237.2 & $4 \%$ & $2 \%$ \\
\hline
\end{tabular}


Appendix B: Major policies related to wind energy diffusion in China, and their association with investment determinants. List of policies based on: (Dai and Xue, 2014; Gosens and Lu, 2013; IRENA and GWEC, 2012; Lewis, 2012)

\begin{tabular}{|c|c|c|c|c|c|c|c|c|c|c|}
\hline \multirow[b]{2}{*}{ Year } & \multirow[b]{2}{*}{ Key Policies in China } & \multicolumn{6}{|c|}{ Risks and Uncertainties } & \multicolumn{3}{|c|}{ Returns } \\
\hline & & $\begin{array}{l}\text { Resource, } \\
\text { Technology } \\
\text { Availability }\end{array}$ & $\begin{array}{l}\text { Financing } \\
\text { Availability }\end{array}$ & $\begin{array}{c}\text { Project } \\
\text { Implementa } \\
\text { tion }\end{array}$ & Grid & $\begin{array}{c}\text { Counter- } \\
\text { party }\end{array}$ & $\begin{array}{l}\text { Power } \\
\text { Market }\end{array}$ & $\begin{array}{c}\text { Fiscal- } \\
\text { based }\end{array}$ & $\begin{array}{l}\text { Price- } \\
\text { based }\end{array}$ & $\begin{array}{l}\text { Quantity- } \\
\text { based }\end{array}$ \\
\hline 1986 & $\begin{array}{l}\text { - First successful grid-connected demonstration project } \\
\text { - } 7 \text { th FYP promoting indigenous development of } 150 \mathrm{~kW}-300 \mathrm{~kW} \text { turbines }\end{array}$ & $\mathrm{x}$ & & & & & & & & \\
\hline 1991 & - 8th FYP promoting R\&D for $150 \mathrm{~kW}$ to $300 \mathrm{~kW}$ turbines & $\mathrm{x}$ & & & & & & & & \\
\hline 1994 & - Provisions for Grid-Connected Wind Power Management for purchasing price based on generation cost-plus-profit, borne by grid corporations & & & & $\mathrm{x}$ & & & & $\mathrm{X}$ & \\
\hline 1996 & $\begin{array}{l}\text { - New and Renewable Energy Development Outline: targets of } 300 \mathrm{MW} \text { (by 2000), } 1000 \mathrm{MW} \text { (by 2010), developing production capacity } \\
\text { - 9th FYP and National High Tech R\&D Program ( } 863 \text { Program): funds for development of a } 600 \mathrm{~kW} \text { wind turbine by domestic manufacturers } \\
\text { with help of foreign technology, with } 40 \% \text { local content } \\
\text { - Loans for Wind Farm Development: low interest rates for setting up windfarms with a preference for local content }\end{array}$ & $\mathrm{x}$ & & & & & $\mathrm{x}$ & & & \\
\hline 1997 & $\begin{array}{l}\text { - Double Increase Programme with preferential loans to double wind capacity and install } 120 \mathrm{MW} \text {, develop manufacturing bases } \\
\text { - Ride the Wind project: targets } 400 \mathrm{MW} \text { (by 2000), supports development of } 300-600 \mathrm{~kW} \text { turbines with } 40 \% \text { local content }\end{array}$ & $\mathrm{x}$ & $\mathrm{x}$ & & & & $\mathrm{x}$ & & & \\
\hline 1998 & - Further Modifications to Import Duties on Wind Turbine Components: components exempt from VAT to promote domestic manufacturing & $\mathrm{X}$ & & & & & & & & \\
\hline 1999 & - Notice on next steps in developing renewable energy: low interest loans, power purchase prices, preferred domestic manufacturer & $\mathrm{X}$ & $\mathrm{x}$ & & & & $\mathrm{x}$ & & $\mathrm{x}$ & \\
\hline 2000 & • National Debt Wind Power Programme: government loans to develop $73.5 \mathrm{MW}$ of wind farms & & $\mathrm{x}$ & & & & $\mathrm{x}$ & & & \\
\hline 2001 & $\begin{array}{l}\text { - 10th FYP target of } 500 \mathrm{MW} \text { and continue 'Ride the Wind', increase localization rate from } 40 \% \text { to } 70 \% \text {, mandatory market share } \\
\text { - Target of } 1200 \mathrm{MW} \text { cumulative capacity (by 2005) in } 100 \mathrm{MW}+\text { parks; increase annual domestic production capacity } \\
\text { - } 863 \text { Program for the development of megawatt-size wind turbines and R\&D from Chinese companies } \\
\text { Reduction in price of wind electricity due to change in VAT from } 17 \% \text { to } 8.5 \%\end{array}$ & $\mathrm{x}$ & & & & & $\mathrm{x}$ & $\mathrm{x}$ & $\mathrm{x}$ & \\
\hline 2003 & $\begin{array}{l}\text { - Concession projects: tenders based on competitive bidding system to develop wind farm sites pre-selected by the NDRC. Winning bidders } \\
\text { guaranteed permits for site development, power purchase agreements, grid connection, and financial support through preferential taxes and loans. } \\
\text { Minimum localization rate at } 50 \%(2003) \text { and } 70 \%(2004-2007)\end{array}$ & $\mathrm{x}$ & $\mathrm{x}$ & $\mathrm{x}$ & $\mathrm{x}$ & $\mathrm{x}$ & & & & $\mathrm{x}$ \\
\hline 2005 & $\begin{array}{l}\text { - Measures for Operation and Management of Clean Development Mechanism Projects in China set guidelines for CDM project development, } \\
\text { carbon finance certified emissions reductions, tax incentives } \\
\text { - Notice on the Relevant Requirements for the Administration of the Construction of Wind Farms for improving project approval process, } \\
\text { proximity to the grid and share of domestically manufactured content } \\
\text { - Corporate Income Tax at a reduced rate of } 15 \% ; 3 \text { year tax-holiday, financial subsidies for qualifying EPC projects }\end{array}$ & , & $\mathrm{x}$ & $\mathrm{x}$ & & & & $\mathrm{x}$ & $\mathrm{x}$ & \\
\hline 2006 & $\begin{array}{l}\text { - Renewable energy law required compulsory grid connection, full purchase of renewable power with an electricity surcharge to recover costs, } \\
\text { called for national resource assessment surveys } \\
\text { - Interim measures on renewable energy price and cost-sharing management set power pricing mechanisms } \\
\text { - } 863 \text { Program supported development of MW-size wind turbines }\end{array}$ & $\mathrm{x}$ & & & $\mathrm{x}$ & $\mathrm{x}$ & $\mathrm{x}$ & & $\mathrm{x}$ & \\
\hline 2007 & $\begin{array}{l}\text { - Medium and long term RE development plan targets of } 10 \% \text { of total energy use from renewable sources by } 2010 ; 15 \% \text { by } 2020 ; 5 \mathrm{GW} \text { wind } \\
\text { power by } 2010 ; 30 \mathrm{GW} \text { by } 2020 ; \text { including } 1 \mathrm{GW} \text { of offshore power. Power companies with more than } 5 \mathrm{GW} \text { of generation to have mandatory } \\
\text { share of } 3 \% \text { of non-hydro RE by } 2010 \text { and } 8 \% \text { by } 2020 \text {. } \\
\text { - Interim Measures on Revenue Allocation from the Renewable Surcharge for bearing costs of electricity }\end{array}$ & & & & & $\mathrm{x}$ & $\mathrm{X}$ & & & $\mathrm{X}$ \\
\hline 2008 & $\begin{array}{l}\text { - } 11 \text { th FYP for Renewable Energy set target of } 10 \mathrm{GW} \text { wind power by } 2010,5 \text { parks with } 1 \mathrm{GW}+\text { capacity, } 1 \mathrm{GW} \text { of offshore; domestic production } \\
\text { capabilities, wind power bases of at least } 10 \mathrm{GW} \text {, transmission planning framework } \\
\text { - Interim measures for administration of special funds for the wind power equipment industry R\&D fund for Chinese controlled firms }\end{array}$ & $\mathrm{X}$ & & & $\mathrm{X}$ & & $\mathrm{X}$ & & & \\
\hline 2009 & $\begin{array}{l}\text { - Notice on Improving Grid-Connected Wind Power Tariff Policy Nationally determined feed-in tariff (FIT) with standardized national feed-in } \\
\text { tariffs varying by wind resource class } \\
\text { - Amendment to renewable energy law: support full purchase of RE power, grid connection, increase investment on grid management } \\
\text { - Notice on Abolishing the Localization Rate Requirement for Equipment Procurement in Wind Power Projects removed the local content } \\
\text { requirement for turbine technology }\end{array}$ & & & & $X$ & $\mathrm{X}$ & $\mathrm{X}$ & & $\mathrm{X}$ & \\
\hline 2010 & $\begin{array}{l}\text { - Wind power equipment manufacturing industry access standards for consolidation of manufacturing industry } \\
\text { - Modifications to Import Duties on Wind Turbine Components removed duties on components to manufacture advanced turbines }\end{array}$ & $\mathrm{X}$ & & & & & & & & \\
\hline 2011 & $\begin{array}{l}\text { - Notice on Strengthening the Management of Wind Power Plant Grid Integration and Operation to address issues in interconnection and frequent } \\
\text { wind power curtailments, by establishing new grid codes, and NEA approval. } \\
\text { - Provisional Management Methods for Wind Power Forecasting for improving grid integration }\end{array}$ & & & & $\mathrm{X}$ & & & & & \\
\hline 2012 & $\begin{array}{l}\text { - 12th FYP: development of wind power science and technology, standards, testing, personnel training; reach international quality levels by } 2015 \\
\text { through design, production, and operation of 3-5 MW direct drive turbines, and } 7-10 \mathrm{MW} \text { turbines and components. } \\
\text { - Planning, development and operation of very large scale farms, including grid integration }\end{array}$ & $\mathrm{X}$ & & $\mathrm{X}$ & $\mathrm{X}$ & & $\mathrm{X}$ & & & \\
\hline
\end{tabular}


Appendix C: Major policies related to wind energy diffusion in India, and their association with investment determinants. List of policies based on: (Ganesan et al., 2014; IRENA and GWEC, 2012; Jolly and Raven, 2013; Mizuno, 2007)

\begin{tabular}{|c|c|c|c|c|c|c|c|c|c|c|}
\hline \multirow[b]{2}{*}{ Year } & \multirow[b]{2}{*}{ Key Policies in India } & \multicolumn{6}{|c|}{ Risks and Uncertainties } & \multicolumn{3}{|c|}{ Returns } \\
\hline & & $\begin{array}{l}\text { Resource, } \\
\text { Technology } \\
\text { Availability }\end{array}$ & $\begin{array}{c}\text { Financing } \\
\text { Availability }\end{array}$ & $\begin{array}{l}\text { Project } \\
\text { Implementa } \\
\text { tion }\end{array}$ & Grid & $\begin{array}{c}\text { Counter- } \\
\text { party }\end{array}$ & $\begin{array}{l}\text { Power } \\
\text { Market }\end{array}$ & $\begin{array}{c}\text { Fiscal- } \\
\text { based }\end{array}$ & $\begin{array}{l}\text { Price- } \\
\text { based }\end{array}$ & $\begin{array}{l}\text { Quantity- } \\
\text { based }\end{array}$ \\
\hline 1985 & $\begin{array}{l}\text { - National wind resource assessment program } \\
\text { - } 7 \text { th FYP supports indigenous wind energy technology improvement and cost reduction }\end{array}$ & $\mathrm{x}$ & & & & & & & & \\
\hline 1986 & - First successful grid-connected demonstration projects with Danish partners & $\mathrm{x}$ & & & & & & & & \\
\hline 1989 & $\begin{array}{l}\text { - Tax Scheme to deduct equipment costs from pre-tax profits } \\
\text { - IREDA established for giving loans to manufacturers, state electricity boards and nodal agencies, for renewable energy development }\end{array}$ & $\mathrm{x}$ & $\mathrm{x}$ & & & & & $\mathrm{x}$ & & \\
\hline 1991 & $\begin{array}{l}\text { - IREDA provides financing of wind power projects with bilateral, multilateral and private sector aid } \\
\text { - Electricity Laws (Amendment) Act to promote private sector participation in wind energy, ease industrial clearances }\end{array}$ & & $\mathrm{x}$ & $\mathrm{x}$ & & & & & & \\
\hline 1992 & $\begin{array}{l}\text { - 8th FYP target of } 500 \mathrm{MW} \text { with private sector participation, focus on commercialization of wind energy technology } \\
\text { - } 100 \% \text { FDI allowed for the manufacturing industry }\end{array}$ & $\mathrm{x}$ & & & & & $\mathrm{x}$ & & & \\
\hline 1993 & $\begin{array}{l}\text { - Manufacturers exempt from paying excise duty and sales tax, while import duty rates on raw materials favor imports } \\
\text { - Income tax rules that allow zero-tax planning, } 100 \% \text { tax holiday on income sales from wind electricity for } 5 \text { years, } 100 \% \text { accelerated } \\
\text { depreciation on capital investment in first year } \\
\text { - MNES Guidelines for grid-connected wind energy producers for captive power or third-party sales, wheeling and banking of electricity, } \\
\text { purchase from the producer through feed-in-tariffs, suggestions on technical standards for grid-integration } \\
\text { - World Bank's Renewable Resources Development (RRD) project implemented through IREDA to increase the uptake of RE (1993-1999) }\end{array}$ & $\mathrm{x}$ & $\mathrm{x}$ & & $\mathrm{x}$ & $\mathrm{X}$ & $\mathrm{x}$ & $\mathrm{x}$ & $\mathrm{x}$ & \\
\hline 1994 & $\begin{array}{l}\text { - Wind energy estates facilitated partnerships between private developer, state government enterprises and the MNES/IREDA by performing all } \\
\text { tasks of development and execution on behalf of the investors (or owners). }\end{array}$ & & & $\mathrm{x}$ & & & & & & \\
\hline 1995 & • Guidelines for wind power projects to utilize wind resource assessment, get turbine approval as a quality check from foreign agencies & & & $\mathrm{x}$ & & & & & & \\
\hline 1996 & $\begin{array}{l}\text { - Guidelines for wind power projects mandated no-objection certificates, detailed project report with focus on quality and grid-connection } \\
\text { - Turbine Approval and Certification prohibited second hand turbines from abroad, made third-party testing mandatory, addressed quality } \\
\text { aspects related to grid connection }\end{array}$ & & & $\mathrm{x}$ & $\mathrm{x}$ & & & & & \\
\hline 1997 & $\begin{array}{l}\text { - Import duty rates on raw materials removed, duties on components introduced to encouraging local manufacturing } \\
\text { - Reduction in corporate tax rate, Minimum Alternate Tax (MAT) introduced on book value profits (MAT acted as a disincentive) } \\
\text { - 9th FYP target of } 1000 \mathrm{MW}\end{array}$ & $\mathrm{x}$ & & & & & $\mathrm{x}$ & $\mathrm{x}$ & & \\
\hline 1998 & $\begin{array}{l}\text { - CWET established } \\
\text { - Large spare parts to pay excise duty and sales tax to encourage high quality production and avoid replacement }\end{array}$ & $\mathrm{x}$ & & $\mathrm{x}$ & & & & & & \\
\hline 1999 & - Technology Upgradation Front: $5 \%$ reimbursement on loan interests, targeted at the textile industry that used wind energy for captive power & & & & & & & $\mathrm{x}$ & & \\
\hline 2000 & - CWET to validate and verify new turbines & & & $\mathrm{X}$ & & & & & & \\
\hline 2001 & - 10 year tax holiday on income from sales of wind electricity & & & & & & & $\mathrm{x}$ & & \\
\hline 2002 & - 10th FYP target of $1500 \mathrm{MW}$ & & & & & & $\mathrm{x}$ & & & \\
\hline 2003 & $\begin{array}{l}\text { - Indian Electricity Act: nationwide promotion of renewable energy; systemic reforms in the electricity sector, deregulation and measures to } \\
\text { improve financial state of discoms }\end{array}$ & & & & & $\mathrm{x}$ & $\mathrm{x}$ & & & \\
\hline 2005 & $\begin{array}{l}\text { - National Electricity policy mentioned conditions for promoting renewable energy; renewable purchase obligations and preferential tariffs for } \\
\text { purchase of electricity generated from wind power projects } \\
\text { - CDM and certified emission reduction credits markets introduced, projects registered with Ministry of Environment and Forests }\end{array}$ & & & & & & $\mathrm{x}$ & & $\mathrm{x}$ & \\
\hline 2006 & $\begin{array}{l}\text { - Integrated Energy Policy suggests } 5 \% \text { renewable energy in the overall energy mix by 2032, competitive energy markets and RPOs } \\
\text { - National tariff policy: SERCs mandated to fix a minimum percentage of RPOs }\end{array}$ & & & & & & $\mathrm{x}$ & & & $\mathrm{x}$ \\
\hline 2007 & - 11th FYP: target of $10500 \mathrm{MW}$ of renewable energy & & & & & & $\mathrm{x}$ & & & \\
\hline 2008 & $\begin{array}{l}\text { - National Action Plan on Climate Change: } 15 \% \text { RE by } 2020 \\
\text { - Open Access Regulations: Introduction of Indian Energy Exchange and Power Exchange India Limited, support for third party sales }\end{array}$ & & & & & $\mathrm{x}$ & $\mathrm{x}$ & & & $\mathrm{x}$ \\
\hline 2009 & $\begin{array}{l}\text { - } 100 \% \text { FDI in renewable energy distribution and generation } \\
\text { - Generation Based Incentives for grid-connected wind power to incentivize performance, attract investors who do not benefit from tax breaks } \\
\text { - Central Electricity Regulatory Commission (CERC) tariff regulations for wind power }\end{array}$ & & $\mathrm{x}$ & & $\mathrm{x}$ & $\mathrm{X}$ & $\mathrm{X}$ & & $\mathrm{x}$ & \\
\hline 2010 & $\begin{array}{l}\text { - Terms and conditions for Renewable Energy Certificates introduced by CERC and Integrated Energy Grid Code (IEGC) launched } \\
\text { - National Clean Energy Fund for research and innovative projects in clean energy technologies }\end{array}$ & $\mathrm{x}$ & & & $\mathrm{x}$ & & & & & $\mathrm{x}$ \\
\hline 2011 & - National Manufacturing Policy: Technology Acquisition and Development Fund targeting wind energy & $\mathrm{x}$ & & & & & & & & \\
\hline 2012 & - 12th Five year plan announcing renewable energy capacity addition of $15000 \mathrm{MW}$ & & & & & & $\mathrm{X}$ & & & \\
\hline
\end{tabular}


